\title{
Plant glucose transporter structure and function
}

\author{
Dietmar Geiger ${ }^{1}$ (D)
}

Received: 11 July 2020 / Revised: 6 August 2020 / Accepted: 10 August 2020 / Published online: 26 August 2020

(C) The Author(s) 2020, corrected publication 2021

\begin{abstract}
The carbohydrate D-glucose is the main source of energy in living organisms. In contrast to animals, as well as most fungi, bacteria, and archaea, plants are capable to synthesize a surplus of sugars characterizing them as autothrophic organisms. Thus, plants are de facto the source of all food on earth, either directly or indirectly via feed to livestock. Glucose is stored as polymeric glucan, in animals as glycogen and in plants as starch. Despite serving a general source for metabolic energy and energy storage, glucose is the main building block for cellulose synthesis and represents the metabolic starting point of carboxylate- and amino acid synthesis. Finally yet importantly, glucose functions as signalling molecule conveying the plant metabolic status for adjustment of growth, development, and survival. Therefore, cell-to-cell and long-distance transport of photoassimilates/ sugars throughout the plant body require the fine-tuned activity of sugar transporters facilitating the transport across membranes. The functional plant counterparts of the animal sodium/glucose transporters (SGLTs) are represented by the proton-coupled sugar transport proteins (STPs) of the plant monosaccharide transporter(-like) family (MST). In the framework of this special issue on "Glucose Transporters in Health and Disease," this review gives an overview of the function and structure of plant STPs in comparison to the respective knowledge obtained with the animal $\mathrm{Na}^{+}$-coupled glucose transporters (SGLTs).
\end{abstract}

Keywords STP $\cdot$ Sugar transport protein $\cdot$ Glucose transport $\cdot$ Plant photoassimilate partitioning

\section{Introduction}

Larger body size and an increase in complexity is a major trend in animal and plant evolution. Unicellular and multicellular organisms depend on diffusion to supply gases (oxygen, carbon dioxide) and nutrients as well as to remove toxic compounds. However, diffusion represents a slow process and works only across small distances $(<1 \mathrm{~mm}$; [70]). With the appearance of organisms with a larger body size, the surface area cannot meet the needs of its volume in terms of nutrient and gas supply [34, 92]. To deliver essential substances to and from each cell in the body, the need arose to evolve internal transport systems to provide bulk flow transport.

In both, higher plants and animals, long-distance transport of carbohydrates is realized by a system of specialized tubes.

This article is published as part of the Special Issue on "Glucose Transporters in Health and Disease"

Dietmar Geiger

geiger@botanik.uni-wuerzburg.de

1 Institute for Molecular Plant Physiology and Biophysics, Julius-von-Sachs-Institute, Biocenter, University of Wuerzburg, 97082 Wuerzburg, Germany
In vertebrates, the vasculature forms a circulatory system of arteries, capillaries, and veins. In the closed circulatory system of vertebrates, blood circulates in the vascular system around and between all tissue layers in the body constantly driven by a pump - the heard. Thereby, the diffusion distance for gas, nutrient, and waste transport to individual cells is reduced. Pressure/flow rate, the composition of the blood, and last but not least, the glucose content are strictly controlled.

\section{Plants do it differently}

In plants, the situation is quite different: long-distance transport is not circulatory. More than 500 million years ago, the first plants conquered the land, and about 470 million years ago, the land plant lineage diverged into bryophytes (including liverworts and mosses) and vascular plants [71, 185]. In early land plants, longdistance transport occurs in cells arranged end-to-end in longitudinal files with a simplified cytoplasm and modified end walls. This design increased the intra- and intercellular conductivities for efficient bulk transport of nutrients, photoassimilates, and information $[75,76,82,102,111,116,165]$. The degree of specialization of conducting cells/tissues increased from non- 
vascular plants (bryophytes such as hornworts, mosses, and liverwort) to vascular cryptogams (early tracheophytes such as lycophytes and pterophytes) and finally to seed plants [75, 76, $82,102,116,165]$. Higher land plants (vascular plants) evolved vascular bundles with two distinct long-distance transport systems - the xylem and the phloem.

The xylem is a specialized plant tissue carrying water and dissolved minerals from the soil via the root to the shoot. This unidirectional transport pathway represents a continuous duct composed of tracheary elements, fibers, and parenchyma cells. Tracheary elements are dead cells with lignified secondary cell walls $[97,135]$. These cells are elongated tubes with exaggerated ends that are interconnected through gaps in the cell wall (pits) with the ends of neibouring cells. Bulk flow of xylem sap is driven by transpiration at the leave surface utilizing the water potential difference between the soil and the atmosphere.

The phloem transports mainly photoassimilates, amino acids, and information in form of, e.g., phytohormones or small RNAs. The transport in the phloem is bidirectional originating from autotrophic sites where $\mathrm{CO}_{2}$ fixation takes place (source tissues) to heterotrophic tissues (sink tissues) such as developing leaves, meristems, roots, and reproductive organs that rely on an adequate sugar-supply by the phloem $[55,141,165,169$, 170] (Fig. 1). The phloem network is assembled by highly active companion cells (CCs) and adjacent nucleus- and vacuole-free interconnected sieve elements (SEs) with increased intracellular conductivity for efficient bulk transport (Fig. 1). In apoplastically loading plants, the surplus of carbohydrates from source leaves are distributed in the plant throughout the vascular system (phloem) mainly in the form of the disaccharide sucrose (Fig. 1, [186]). Membrane-localized sucrose $/ \mathrm{H}^{+}$symporters (SUTs or SUCs) accumulate sucrose in the phloem cells in source tissues where sucrose can reach concentrations of up $1 \mathrm{M}[15,39,41,68,77,78,118,120$, 137, 141, 142, 148, 149]. The hydrostatic pressure difference between source (sites of sugar accumulation) and sink (sites of sugar release) tissues drives the mass flow of water and nutrients in the phloem vessels $[61,96]$.

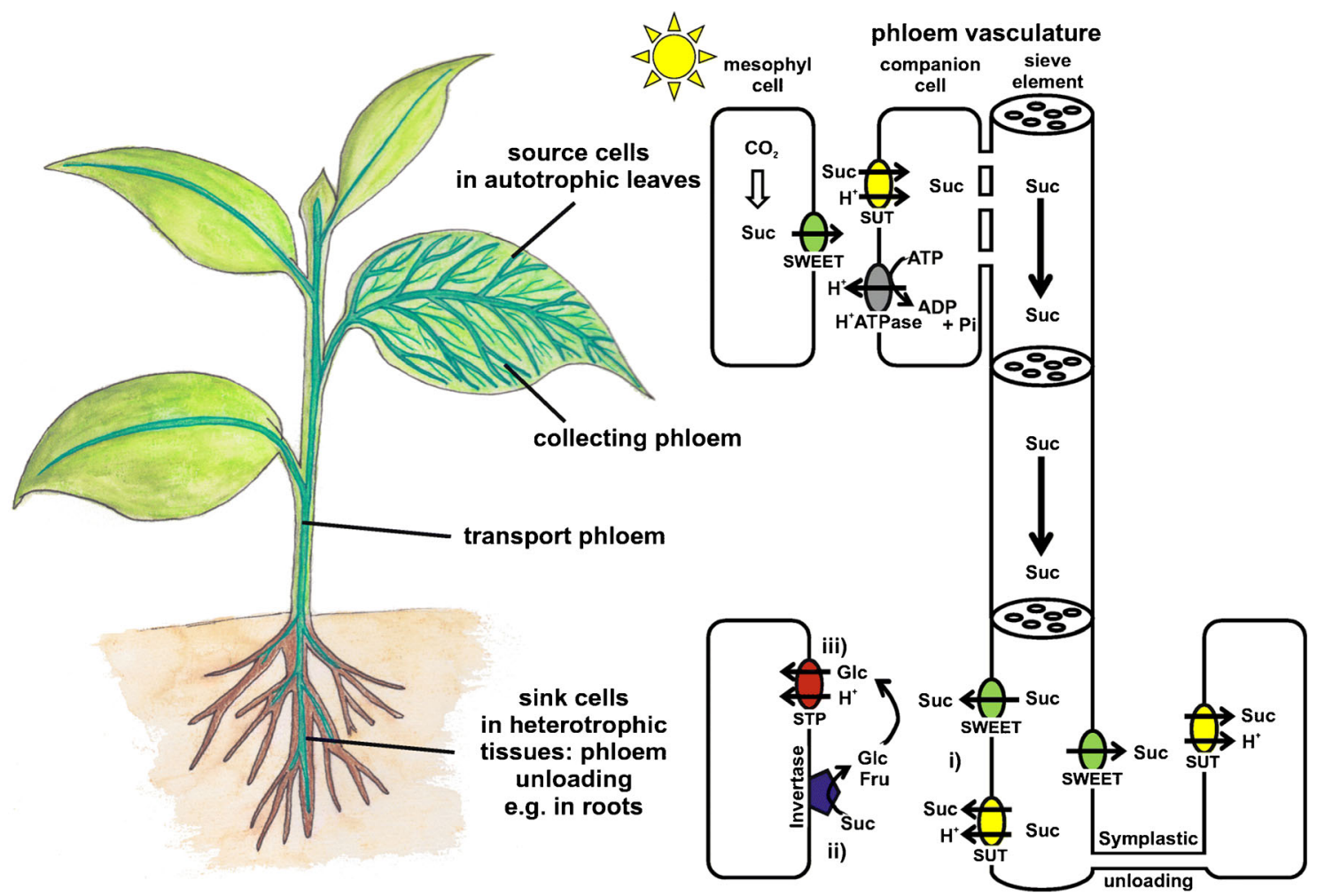

Fig. 1 Long-distance transport of sucrose from source to sink tissues in apoplastically loading plants and the involvement of STPs in loading of sink cells with monosaccharides. Left: cartoon of a plant showing the phloem vasculature in dark green. The branched collecting phloem is illustrated only in the right fully developed leaf. Right: Illustration of the loading, the long-distance transport and the unloading of photoassimilates. In plants, photosynthetically synthesized sucrose is released from mesophyll cells to the apoplast (extracellular cell wall space) via SWEET type facilitators. At the source site of the phloem vasculature, $\mathrm{H}^{+}$-coupled sucrose transporters (SUTs) accumulate sucrose in the SE/CC (sieve element/companion cell complex — phloem tissue) complex for long-distance distribution throughout the plant body. $\mathrm{H}^{+}$-ATPase provide the proton motive force for sucrose loading energized by ATP hydrolysis. To provide heterotrophic sink cells with photoassimilates, sucrose is either imported symplastically via plasmodesmata or via a three-step apoplastic sugar import: (i) sucrose is released from the phloem cells into the apoplasm, (ii) cell wall-bound invertases hydrolyse sucrose to fructose and glucose, (iii) followed by the uptake of the breakdown products into sink cells via STP-type proton-coupled monosaccharide transporters 


\section{Why plants use sucrose instead of glucose for long-distance transport}

As stated previously, long-distance transport of photoassimilates is mainly realized in the form of the disaccharide sucrose or less frequently, galactosides of sucrose (sugars of the raffinose family) $[118,186]$ and not in form of glucose as it is the case in animals. Sucrose is synthesized in photosynthetically active cells from fructose and glucose and is then transported via the phloem to heterotrophic parts of the plant. Sucrose transport is favorable for the following reasons: (i) 1 mol sucrose contains more energy than $1 \mathrm{~mol}$ of a monosaccharide such as glucose or fructose, thus using the disaccharide is more energy efficient for transport and storage. (ii) In contrast to fructose and glucose, sucrose represents a non-reducing sugar, meaning that it cannot be oxidized and thus no intermediate reactions with other molecules occur. High concentrations of reducing sugars and amino acid residues can undergo non-enzymatic glycosylation [85] leading to the impairment/damage of critical proteins [7, 159, 181]. Thus, plant cells sequester reducing sugars into the vacuole (Fig. 3) to avoid non-controllable glycosylation of cytosolic proteins [10]. During long-distance transport in living companion cells and sieve tubes of the phloem, sugar concentrations reach several hundred millimolar up to $1 \mathrm{M}$. The use of hexoses for transport at these high concentrations in the cytosol of phloem cells would lead to massive damages due to glycolysation. In vertebrates, long-distance transport is realized in the form of glucose extracellularly circulating in the bloodstream. The blood glucose concentration is tightly regulated to values in the low millimolar range $(5.5 \mathrm{mmol} / \mathrm{L}$ global mean fasting plasma blood glucose level in humans; [25]). Thus, plants prefer the non-reducing sugar sucrose (or galactosides of sucrose) for long-distance transport [186]. In sink tissues, sucrose is converted back to glucose and fructose by an enzyme called (cell wall-bound) invertase (Fig. 1, [89, 121, 139, 167]). Subsequently, these hexoses are taken up by sink cells for consumption or storage. The uptake of hexoses across the plasma membrane is facilitated by a family of protoncoupled sugar transport proteins (STPs) - the counterpart of sodium-coupled glucose transporters of the SGLT-family in vertebrates. The function and the structure of these hexosetransporting proteins is the subject of this review.

\section{Proton-coupled versus sodium-coupled secondary active transport}

Transporters mediate the accumulation of substrates by coupling the substrate transport to a thermodynamically favorable symport or antiport of ions (usually $\mathrm{Na}^{+}$or $\mathrm{H}^{+}$). Mitchell already in 1963 hypothesized the utilization of free energy stored in electrochemical ion gradients for substrate translocation [91]. ATP-driven primary active pumps-Ptype $\mathrm{H}^{+}$-ATPases in the case of plants or $\mathrm{Na}^{+} / \mathrm{K}^{+}$-ATPases in animals - establish these electrochemical gradients across biological membranes [95, 104].

Plants utilize proton gradients for secondary active transport whereas animals prefer sodium gradients [98]. When eukaryotes diverged during evolution, plants-just like bacteria - continued using the abundant $\mathrm{H}^{+}$ion to generate proton gradients via P-type $\mathrm{H}^{+}$-ATPases at the plasma membrane or vacuole-type ATPases as well as an $\mathrm{H}^{+}$-translocating pyrophosphatases at the vacuolar membrane $[8,33,104,110$, $136,138]$. The activity of P-type proton pumps is important for membrane potential homeostasis and the strong hyperpolarization of plant membranes of more than $-200 \mathrm{mV}$ [47]. Moreover, the accumulation of protons on the outside creates an inward-directed proton gradient with $\mathrm{pH}$ values of around 5.5 in the apoplast whereas the cytosolic $\mathrm{pH}$ is kept constant at around $\mathrm{pH} 7.5$ [104, 157]. This proton motive force (proton gradients in conjunction with the hyperpolarized membrane potentials) are utilized by $\mathrm{H}^{+}$-coupled transporters for substrate transport/accumulation via $\mathrm{H}^{+} /$substrate symport or antiport mechanisms. Given a tight coupling between substrate and $\mathrm{H}^{+}$transport, the free energy stored in the electrochemical proton gradient allows for a more than 1,000-fold accumulation of the substrate [20]. Animals evolved the $\mathrm{Na}^{+} /$ $\mathrm{K}^{+}$ATPase for the maintenance of ionic gradients across the plasma membrane $[49,151,152]$. It creates ionic conditions/ gradients for critical cellular processes such as secondary active transport of solutes and water, for $\mathrm{pH}$ regulation, and for creating and maintaining an electrical potential that is essential for the function of excitable cells in rapid signal transmission systems (e.g., muscles, nerves). $\mathrm{Na}^{+} / \mathrm{K}^{+}$ATPase does not exist in plants.

\section{Phylogenie and physiology of monosaccharide transporters in plants}

Higher plants express two gene families encoding for monosaccharide transporters: the cation/proton-coupled monosaccharide transporter(-like) superfamily (MSTs, $[105,117])$ belonging to the major facilitator superfamily (MFS) and the recently identified SWEET transporter family (sugar will eventually be exported transporters) [23] —-facilitators belonging to a group of transporters distinct from the MFS. An overview of the plant transport proteins and their classification into superfamilies/families is presented in Fig. 2a. The phylogenie and evolution of plant MSTs has comprehensively been reviewed by Johnson et al. previously [53, 54]. MSTs are integral membrane proteins that consist of 12 transmembrane-spanning domains that assemble in a pseudosymmetrical manner to form a central pore/cavity shuttling soluble monosaccharides together with protons across 
a Transport proteins in plants

Channel-mediated transport
- Channels
- Porins

\section{Carrier-mediated transport}

- APC group (Amino acid/Polyamine/organo-Cation)

- MFS group (Major Facilitator Superfamily)

- DMT group (Drug/Metabolite Transporter)

- MC group (Mitochondrial Carrier)

- other cation carrier groups

○ other groups (e.g.SWEETs)

Primary active transport

- ABC group (ATP-Binding Casse)

- V-type ATPase

- P-type ATPase

VHP-type PPase

$\circ$ other groups

\section{Major Facilitator Superfamily}

\section{- MST family}

- SGB/GICT-type hexose transporter

- VGT-type hexose transporter

- INT-type inositol transporter

- AZT-type monosaccharide transporter

- ERD6-type monosaccharide transporter

- STP-type monosaccharide transporter

- PLT-type polyol/monosaccharide transporter

- GPH family

\section{- SUT/SUC-type sugar transporter}

- OCT family

- $\quad$ NRT1/PTR family

- .....

- unspecified MFS family members

b

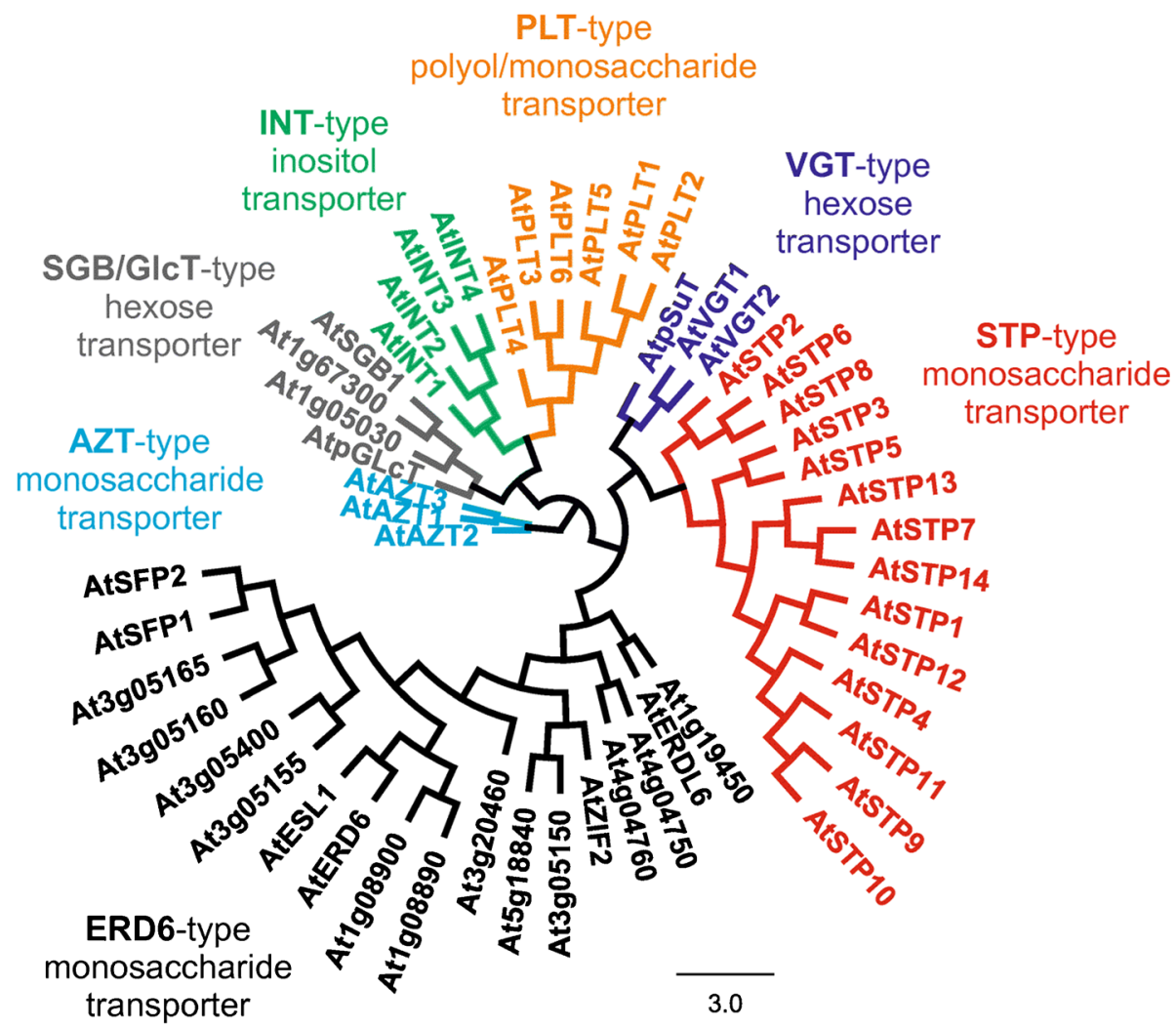

hydrophobic membranes $[18,169]$. In the model plant Arabidopsis thaliana, 53 members fulfil the criteria to represent a member of the MST-family [105, 117] (Fig. 2b). The Arabidopsis transporters of the MST-family divide into seven subfamilies that are conserved across the seed plants despite the variation in total number of family members in different species [53, 54]. Phylogenetic analysis using expressed sequence tag (EST) data showed that the MST gene family is 
Fig. 2 Classification of plant transport proteins. a Plant transport processes comprise proteins for channel-mediated transport, carriermediated transport, and primary active transport. Secondary active sugar transport proteins are members of the major facilitator superfamily (MFS). The subfamily of monosaccharides transporters (MSTs) is further subdivided in seven groups of transporter families: EDR6 (early response to dehydration)-like, STP (sugar transport proteins), pGlcT/SBG1 (plastidic glucose transporter/Supressor of G protein beta1), INT (inositol or cyclic polyol transporters), PLT (polyol/ monosaccharide transporters), AZT/TMT (tonoplastic monosaccharide transporters), and VGT (vacuolar glucose transporters). The family of disaccharide transporters (mainly sucrose transporters) constitute a distinct subfamily within the MFS - the GPH family. Monosaccharide and disaccharide facilitators of the SWEET (sugar will eventually be exported transporters) family are not members of the MFS but group into a distinct structural group of transporters. b Phylogenetic tree of the 53 members of MSTs in the model plant Arabidopsis thaliana. As mentioned in a, the MSTs are subdivided into 7 subfamilies

ancient appearing at least 400 million years ago in land plants and showing differential subfamily expression and lineagespecific subfamily expansions [53]. The seven subfamilies of the plant MST-family (cf. Fig. 2b) consist of two large groups of subfamilies: EDR6 (early response to dehydration)-like and STP (sugar transport proteins) and five small subfamily groups: pGlcT/SBG1 (plastidic glucose transporter/suppressor of G protein beta1), INT (inositol or cyclic polyol transporters), PLT (polyol/monosaccharide transporters), AZT/TMT (tonoplastic monosaccharide transporters), and VGT (vacuolar glucose transporters). An overview of the subcellular localization of MST subfamilies is illustrated in Fig. 3. Although the members of the MSTfamily cluster into distinct subfamilies, several members exhibit overlapping expression patterns, subcellular localizations, and transport similar sugars. Moreover, many of these transporters transport more than one monosaccharide, though affinities for the substrates vary $[17,127,140]$. Only a few members of the MST(-like) superfamily have been shown to be specific for a single substrate such as AtSTP9 for glucose [131] and AtSTP14 for galactose [113].

Since the STP-subfamily is the best characterized plant subfamily of the MST family and since STPs represent the functional counterparts to human SGLTs, this review focuses on the STP-subfamily. The STP subfamily in the model plant Arabidopsis is encoded by 14 highly homologous STP genes [16] (Fig. 2b). AtSTPs have been functionally studied by heterologous expression in yeast or Xenopus oocytes and were shown to catalyse proton/sugar symport across the plasma membrane into the cell (see Table 1 for more information on functional properties of STPs; [16-18, 100, 123, 127, 131, $132,134,161]$ and references therein).

Although gene products of the plant MSTs cluster into phylogenetically distinct subfamilies (Fig. 2b), several transporters show overlapping expression patterns and transport similar sugars. Thus, genetic analyses of many single-gene

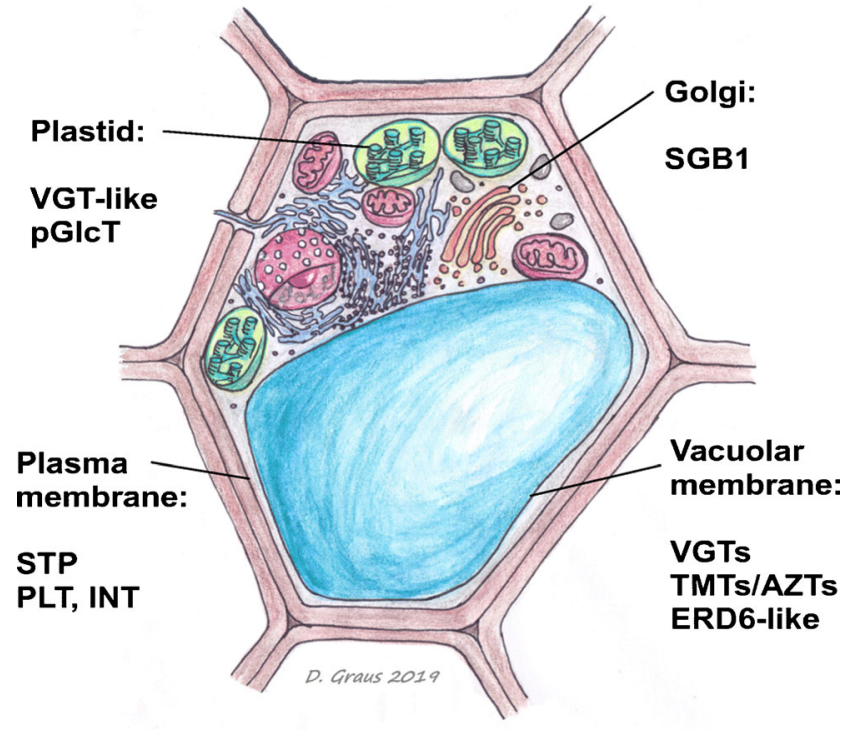

Fig. 3 Cartoon illustrating a plant cell. Subcellular localization of MST subfamily groups is indicated. The subfamilies of the plant MST-family consist of EDR6 (early response to dehydration)-like, STP (sugar transport proteins), pGlcT/SBG1 (plastidic glucose transporter/ Supressor of G protein beta1), INT (inositol or cyclic polyol transporters), PLT (polyol/monosaccharide transporters), AZT/TMT (tonoplastic monosaccharide transporters), and VGT (vacuolar glucose transporters)

knockouts of STPs fail to confer a significant phenotype indicating redundancy among similar transporters compensating the loss-of-function of a single transporter. Thus, linking the physiological role of individual STPs determined by heterologous expression to a specific function in plants appeared to be a major challenge. However, by the use of higher order knockouts generated by crossings and CRISPR/Cas9 or the overexpression of sugar transport proteins, major breakthroughs could be obtained [6, 122, 133].

As mentioned previously, photoassimilates are translocated from source to sink tissues over long distances mainly in form of sucrose [186]. Following the breakdown of sucrose to glucose and fructose via cell wall-bound invertases in the apoplastic space (Fig. 1), STPs are believed to transport the monosaccharides into sink cells, such as developing leaves, roots, pollen, flowers, and seeds [3, 17, 73, 87, 123, 128, 140].

Besides serving as a nutrient, glucose serves as a signalling molecule that is perceived by the enzyme Hexokinase 1 (HXK1) in the cytosol of plant cells [50]. For example, pollen tube germination and growth require metabolic energy that has to be imported from the extracellular space across the plasma membrane in form of carbohydrates (Fig. 4a). Interestingly, however, pollen tube growth arrested upon glucose application [122]. This inhibitory effect was weakened in pollen tubes of a stp4-6-8-9-10-11 sextuple knockout Arabidopsis mutant as well as in the $h x k l$ knockout lines suggesting that STPs are responsible for glucose uptake into the growing pollen tube and that subsequently HXK1 detects the signalling molecule. 
Table 1 Summary of available localization patterns and functional data of the Arabidopsis thaliana STPs

\begin{tabular}{|c|c|c|c|c|c|}
\hline $\begin{array}{l}\text { Gene name } \\
\text { Identifier }\end{array}$ & Tissue localization & $\begin{array}{l}\text { Subcellular } \\
\text { localization }\end{array}$ & $\begin{array}{l}\text { Substrate } \\
\text { specificity }\end{array}$ & $\begin{array}{l}\text { Substrate } \\
\text { affinity }\end{array}$ & References \\
\hline $\begin{array}{l}\text { AtSTP1 } \\
\text { At1g11260 }\end{array}$ & Mainly in leaves and stems & $\begin{array}{l}\text { Plasma } \\
\text { mem- } \\
\text { brane }\end{array}$ & $\begin{array}{l}\text { Glucose, galactose, } \\
\text { mannose, } \\
\text { xylose, } \\
\text { arabinose }\end{array}$ & High & $\begin{array}{l}{[24,35} \\
103,139 \\
150,178]\end{array}$ \\
\hline $\begin{array}{l}\text { AtSTP2 } \\
\text { At1g07340 }\end{array}$ & $\begin{array}{l}\text { Early male gametophyte } \\
\text { development }\end{array}$ & $\begin{array}{l}\text { Plasma } \\
\text { mem- } \\
\text { brane }\end{array}$ & $\begin{array}{l}\text { Glucose, galactose, } \\
\text { mannose, } \\
\text { xylose, } \\
\text { arabinose }\end{array}$ & High & {$[154,161]$} \\
\hline $\begin{array}{l}\text { AtSTP3 } \\
\text { At5g61520 }\end{array}$ & Source leaf & $\begin{array}{c}\text { Plasma } \\
\text { mem- } \\
\text { brane }\end{array}$ & Glucose & Low & [19] \\
\hline $\begin{array}{l}\text { AtSTP4 } \\
\text { At3g19930 }\end{array}$ & Pollen, root tips, leaf & $\begin{array}{l}\text { Plasma } \\
\text { mem- } \\
\text { brane }\end{array}$ & $\begin{array}{l}\text { Glucose, galactose, } \\
\text { mannose, } \\
\text { xylose, } \\
\text { arabinose }\end{array}$ & High & $\begin{array}{r}{[35,36,94,} \\
122,160]\end{array}$ \\
\hline $\begin{array}{l}\text { AtSTP5 } \\
\text { At1g34580 }\end{array}$ & Silique and whole seedling & $\begin{array}{l}\text { Plasma } \\
\text { mem- } \\
\text { brane }\end{array}$ & Non functional? & & \\
\hline $\begin{array}{l}\text { AtSTP6 } \\
\text { At3g05960 }\end{array}$ & $\begin{array}{l}\text { Fully developed pollen } \\
\text { grain }\end{array}$ & $\begin{array}{l}\text { Plasma } \\
\text { mem- } \\
\text { brane }\end{array}$ & $\begin{array}{l}\text { Glucose, galactose, } \\
\text { mannose, } \\
\text { fructose, } \\
\text { arabinose }\end{array}$ & High & {$[122,134]$} \\
\hline $\begin{array}{l}\text { AtSTP7 } \\
\text { At4g02050 }\end{array}$ & $\begin{array}{l}\text { Multiple tissues with high } \\
\text { cell wall turnover except } \\
\text { pollen }\end{array}$ & $\begin{array}{l}\text { Plasma } \\
\text { mem- } \\
\text { brane }\end{array}$ & Arabinose, xylose & High & {$[123]$} \\
\hline $\begin{array}{l}\text { AtSTP8 } \\
\text { At5g26250 }\end{array}$ & $\begin{array}{l}\text { Pollen grains, pollen tubes, } \\
\text { and ovules }\end{array}$ & $\begin{array}{l}\text { Plasma } \\
\text { mem- } \\
\text { brane }\end{array}$ & $\begin{array}{l}\text { Glucose, galactose, } \\
\text { mannose, } \\
\text { arabinose }\end{array}$ & High & {$[122,123]$} \\
\hline $\begin{array}{l}\text { AtSTP9 } \\
\text { At1g50310 }\end{array}$ & $\begin{array}{l}\text { Fully developed pollen } \\
\text { grain }\end{array}$ & $\begin{array}{c}\text { Plasma } \\
\text { mem- } \\
\text { brane }\end{array}$ & $\begin{array}{l}\text { Glucose, galactose, } \\
\text { arabinose }\end{array}$ & High & {$[122,131]$} \\
\hline $\begin{array}{l}\text { AtSTP10 } \\
\text { At3g19940 }\end{array}$ & $\begin{array}{l}\text { Germinating pollen and } \\
\text { growing pollen }\end{array}$ & $\begin{array}{l}\text { Plasma } \\
\text { mem- } \\
\text { brane }\end{array}$ & $\begin{array}{l}\text { Glucose, galactose, } \\
\text { mannose, }\end{array}$ & High & $\begin{array}{c}{[109,122,} \\
124]\end{array}$ \\
\hline $\begin{array}{l}\text { AtSTP11 } \\
\text { At5g23270 }\end{array}$ & $\begin{array}{l}\text { Fully mature pollen and } \\
\text { growing pollen tubes }\end{array}$ & $\begin{array}{l}\text { Plasma } \\
\text { mem- } \\
\text { brane }\end{array}$ & $\begin{array}{l}\text { Glucose, galactose, } \\
\text { mannose, } \\
\text { xylose, } \\
\text { arabinose }\end{array}$ & High & {$[122,132]$} \\
\hline $\begin{array}{l}\text { AtSTP12 } \\
\text { At4g21480 }\end{array}$ & $\begin{array}{l}\text { Multiple tissues except } \\
\text { pollen }\end{array}$ & $\begin{array}{l}\text { Plasma } \\
\text { mem- } \\
\text { brane }\end{array}$ & $\begin{array}{l}\text { Glucose, galactose, } \\
\text { mannose, xylose }\end{array}$ & High & [123] \\
\hline $\begin{array}{l}\text { AtSTP13 } \\
\text { At5g26340 }\end{array}$ & $\begin{array}{l}\text { Source leaves, vascular } \\
\text { tissue of emerging petals, } \\
\text { roots, guard cells, } \\
\text { cotyledons }\end{array}$ & $\begin{array}{l}\text { Plasma } \\
\text { mem- } \\
\text { brane }\end{array}$ & $\begin{array}{l}\text { Glucose, galactose, } \\
\text { mannose, } \\
\text { xylose, fructose, } \\
\text { arabinose }\end{array}$ & High & $\begin{array}{l}{[100,133} \\
177-179]\end{array}$ \\
\hline $\begin{array}{l}\text { AtSTP14 } \\
\text { At1g77210 }\end{array}$ & $\begin{array}{l}\text { Source and sink tissues, } \\
\text { female gametophyte, } \\
\text { seed endosperm and in } \\
\text { cotyledons }\end{array}$ & $\begin{array}{l}\text { Plasma } \\
\text { mem- } \\
\text { brane }\end{array}$ & $\begin{array}{l}\text { Galactose, } \\
\text { arabinose }\end{array}$ & High & [113] \\
\hline
\end{tabular}

Besides supplying sink cells/tissues with sugars, the removal of sugar from the extracellular space has recently been shown to constitute a defense strategy against microbial infection by, e.g., powdery mildew and rust $[9,30,74,90,93,156$, 179] (Fig. 4b). During infection, STP1, 4 and 13 expression, and activity are induced as part of the defense response [36, 179]. Thus, extracellular sugar depletion by STPs restricts the growth and development of microbial invaders (Fig. 4b).
Another model suggests that biotrophic pathogens, such as fungi, may hijacke the plant hexose transporter STP13 to import sugars into the haustorium or import sugars into the cell that feeds the haustorium thereby increasing the availability of sugars in the infected cell [9, 179] (Fig. 4b).

Stomatal complexes - composed of two guard cells in the leaf epidermis - regulate the gas exchange $\left(\mathrm{CO}_{2}\right.$-uptake, $\mathrm{H}_{2} \mathrm{O}$ release) between the plant and the atmosphere in response to 
a

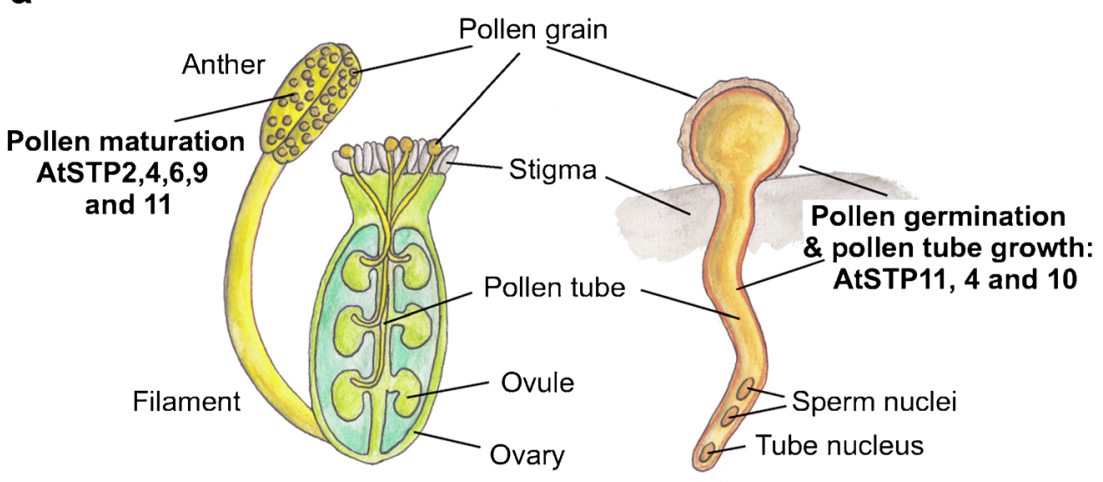

b

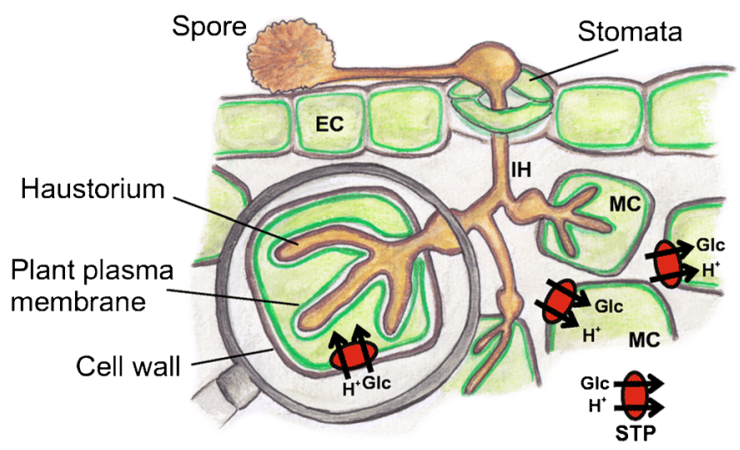

C

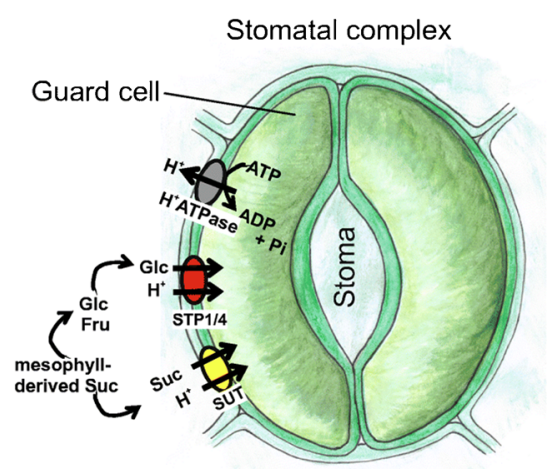

Fig. 4 Cartoons illustrating the localization and function of STPs in various plant cell types. a In Arabidopsis pollen grain development and maturation in the anther of the flower involve the expression of AtSTP2, $4,6,9$, and 11. Pollen grains germinate on the stigma. Pollen tubes enter the top of the pistil through the stigma and travel down the style to the ovules, which are contained in the ovary at the base of the pistil. AtSTP4, 10 , and 11 are involved in pollen tube germination and growth. On the right, a pollen tube is shown in higher magnification. b Cartoon showing a rust infected plant leaf. Germination tubes of spores (S) at the leaf surface enter the leaves through stomata. Primary infection hyphae (IH) propagate through the leaf and penetrate the plant mesophyll cell (MC) wall but not the host plasma membrane to form a feeding structure - the haustorium. During infection, STP1, 4, and 13 expression and activity are induced as part of a defense response [9, 36, 178]. STPs are suggested to lower the apoplastic hexose concentration by moving the sugars into noninfected cells to limit the availability of extracellular saccharides for the pathogen. Another hypothesis implies that the pathogen hijackes STP13 to import sugars into the haustorium or import sugars into the cell that feeds the haustorium with sugars provided from adjacent non-infected cells (Yamada et al. 2016). c Guard cells embedded in the leaf epidermis regulate the stomatal opening for gas exchange $\left(\mathrm{CO}_{2}\right.$-uptake, $\mathrm{H}_{2} \mathrm{O}$ release) between the plant and the atmosphere. In Arabidopsis guard cells, STP1 and 4 import mesophyll-derived glucose into guard cells for starch accumulation and light-induced stomatal opening. Thus, mesophyll-derived glucose uptake by guard cells connects photosynthesis with stomatal movements [35] various stimuli such as, e.g., light, drought, $\mathrm{CO}_{2}$ availability, and pathogens. In Arabidopsis, guard cells express the monosaccharide transporters STP1 and 4 (Fig. 4c). Flütsch et al could very recently show that STP1 and 4 are essential for light-induced stomatal opening and starch accumulation in guard cell. These transporters import mesophyll-derived glucose into guard cells connecting photosynthesis with stomatal movements [35]. 
Glucose transport in humans is accomplished by transporters encoded from two gene families. They are responsible for the absorption of glucose across the small intestine, the reabsorption of glucose from the glomerular filtrate, brain uptake across the blood-brain barrier, and the entire uptake and release of glucose from all kind of cells in the body. One family of glucose transporters facilitate the downhill, passive transport of glucose across cell membranes, the GLUT or SLC2 gene family [164]. Sodium-coupled uphill transport of glucose is mediated by a second gene family, the SGLT or SLC5 gene family [176].

\section{Transport characteristics of plant monosaccharide transporters of the STP family}

STP subfamily orthologs can already be found in the unicellular green algae Chlorella kessleri $>450$ MYBP ago before Bryophytes evolved [22]. When Chlorella kessleri is grown under heterotrophic conditions, glucose serves as sole carbon source. Shifting the algae from carbon autotrophy to heterotrophy, hexose uptake increases more than 200-fold [44, 158]. The transport system for sugars has been associated with proteins encoded by the STP-like HUP (Hexose UPtake) genes (HUP1, 2, and 3). HUP transporters are members of the MFSfamily of transporters just like the bacterial model transporter LacY - $\mathrm{a} \mathrm{H}^{+}$-coupled lactose permease from Escherichia coli [56]. Although the helix packing seems identical to the one derived for the E. coli lac permease, the mechanism for transport and proton coupling seems to differ between the lac permease and the Chlorella symporter [22]. Detailed functional studies characterized HUP-transporters as $\mathrm{H}^{+}$-hexose symporters $[62,64-66]$, transporting sugars and protons with a stoichiometry of $1: 1$. Thereby, HUP1 accumulates substrates more than 1000-fold [63]. This accumulation has been explained by the tight coupling between $\mathrm{H}^{+}$and sugar transport, distinct $\mathrm{K}_{\mathrm{m}}$ values for sugar uptake and release, and partly by differences of velocity constants contributing to uptake compared with those contributing to substrate release [63, 64]. These biochemical and biophysical studies were performed following functional HUP1 expression in different heterologous expression systems, such as yeast strains, Escherichia coli, Volvox carteri, and Xenopus oocytes [4, 126, 127].

Following the functional description of HUP genes from Chlorella, the hexose transporter STP1 from Arabidopsis represented the first cloned and characterized transporter of a higher plant [127]. Heterologous expression in the fission yeast Schizosaccharomyces pombe revealed that AtSTP1 transports glucose with high affinity $(20 \mu \mathrm{M})$, but is also capable of transporting galactose, mannose, and xylose, however, at lower rates compared to glucose [17, 127]. Interestingly, only AtSTP6 and AtSTP13 transport fructose at significant rates $[100,134]$ while AtSTP9 is glucose specific [131]. For substrate specificities and affinities of further functionally characterized STP transporters, see Table 1, e.g., [16-18, $123,124,132,161]$ and references therein). Only little is known about the mechanistic transport cycles of plant monosaccharide transporters. Concerning the kinetic mechanism of monosaccharide- $\mathrm{H}^{+}$symport via STP-like transporters, AtSTP1 is the only member that has been studied in detail so far $[11,12]$. Since kinetic parameters of membrane proteins often show pronounced voltage dependence, Borrer et al. (1994, [12]) expressed AtSTP1 in Xenopus oocytes. In contrast to yeast radiotracer flux analysis, heterologous expression in oocytes followed by two-electrode voltage clamp (TEVC) experiments provides the possibility to study kinetic parameter as a function of sugar and $\mathrm{H}^{+}$concentrations in the membrane of a single cell under well-defined membrane potentials. AtSTP1 expressing oocytes were characterized by transport-associated glucose/3OMG (the non-metabolisable 3-O-methylglucose)-induced inward currents [11]. These transport-associated inward currents resemble the symport of protons (positively charged) with the uncharged sugar molecule. Thereby, $\mathrm{K}_{0.5}$-values of around $100 \mu \mathrm{M}$ at $\mathrm{pH} 6$ were calculated. This value in the low micromolar range is well in line with the affinity of AtSTP1 towards glucose determined in yeast $(60 \mu \mathrm{M} \mathrm{pH} 6$; [127]) and hexose uptake assays performed in higher plant protoplasts, cells, or tissue slices with $\mathrm{K}_{\mathrm{m}}$-values in the range of 100-300 $\mu \mathrm{M}$ [115]. The highaffinity sugar uptake by STPs was later on further confirmed by sugar uptake studies in Arabidopsis seedlings comparing wild-type and an atstp 1-KO mutant [139]. These data demonstrate that kinetic studies in heterologous expression systems can reflect the properties of sugar transporters in plants.

Furthermore, Borrer et al (1994, [12]) determined a Hill coefficient ( $\mathrm{n}$; cooperativity coefficient) for both protons and glucose of $1 . \mathrm{n}$ for glucose appeared independent from the external $\mathrm{pH}$, suggesting that AtSTP1 transports $\mathrm{H}^{+}$and glucose in a 1 to 1 stoichiometry. In order to further explore the molecular mechanism of AtSTP1 proton-coupled glucose transport and the underlying transport cycle, pre-steady-state currents $\left(\mathrm{I}_{\text {pre }}\right)$ of AtSTP1-expressing oocytes were measured (cf. [13, 21]). Most cation-coupled transporters characteristically display at least two main kinds of electrical currents: besides the organic substrate-associated ion translocation (transport-associated $\mathrm{H}^{+} / \mathrm{Na}^{+}$currents, $\mathrm{I}_{\mathrm{tr}}$ ), co-transporters exhibit pre-steady-state currents $\left(\mathrm{I}_{\text {pre }}\right.$, arising from charge movements in the electric field of the membrane) $[45,79,107,153]$. While the pre-steady-state current is best observed in the absence of substrate, it disappears when the latter is present in saturating amounts $[13,81,84,101]$. AtSTP1 pre-steady state currents displayed a similar behavior. In the absence of glucose and an external $\mathrm{pH}$ of 5.5, these transients could be described by an exponential equation and therein the decay rate constant (s) of $\mathrm{I}_{\text {pre }}$ and the quantity of displaced charges (Q) 
could be calculated. The observation that these transient currents vanished at saturating substrate concentrations or at neutral external $\mathrm{pH}$ values indicate that $\mathrm{I}_{\text {pre }}$ resemble the binding of protons to a site of AtSTP1 in the electrical field of the membrane or that conformational changes move charged residues that are located in the electrical field. Based on their kinetic studies, Boorer et al 1994 proposed a six-state transport cycle for AtSTP1 [12], where protons and sugars bind sequentially to the outward facing conformation of the transporter. The loaded transporter undergoes a conformational change presenting the binding sites for the sugar and protons to the cytosolic side of the membrane. Following the release of the substrates, the transporter reorientates in the membrane and thereby finalizes its transport cycle.

SGLT1, the functional animal counterpart of plant STPs, was also expressed and extensively studied in Xenopus oocytes using electron microscopic and optical methods as well as radioactive tracer flux analysis and electrophysiological techniques, summarized in [174]. In contrast to protoncoupled STP transporters, the rate and direction of sugar transport via SGLT1 was shown to depend on the magnitude and direction of the sodium electrochemical potential gradients with a fixed stoichiometry of $2 \mathrm{Na}^{+}$ions to 1 glucose molecule per transport cycle [31, 114, 162]. Interestingly, protons can drive glucose transport of SGLT1 as well-just like glucose transport via STPs - however, the affinity for sugar is about an order of magnitude lower than in the presence of sodium [173]. Vice versa, dependent on the individual transporter, the magnitude of transport currents but not the affinity towards the substrate of plant proton-coupled sucrose transporters seems to be influenced by high external sodium concentrations [183]. In the case of STPs, the influence of sodium on the hexose transport characteristics was not tested.

The $\mathrm{K}_{0.5}$ of SGLT1 for glucose and galactose is equal at $0.5 \mathrm{mM}$ whereas SGLT2 seem to be glucose specific with a $\mathrm{K}_{0.5}$ of $2 \mathrm{mM}$. Just like a thermodynamically perfect machine, the transport direction of SGLT1 was fully reversible with a functional asymmetry between its cytosolic and extracellular face in respect to sugar affinity, sugar selectivity, and inhibitor susceptibility (phlorizin) [31, 106, 107, 114] cf. [20]. These studies revealed an essential ordered six-state kinetic model for Na/glucose cotransport by SGLT1. After the binding of two $\mathrm{Na}^{+}$ions on the external surface, glucose binds to the outward-directed SGLT1 transporter. Due to a conformational change, sodium ions together with one glucose molecule are transported across the membrane, where glucose and the ions dissociate into the cytosol. The empty binding sites then reorientate from the inner to the external surface to complete the transport cycle [107]. Thus, studies of AtSTP1 [12] and SGLT1 [107] in oocytes revealed a similar essential six-state model.

Plant sugar transporters of the MST family group into the same structural major facilitator superfamily (MFS; [125]) as the model transporters LacY, while the animal $\mathrm{Na}^{+} /$ Glucose cotransporters SGLTs belong to the large sodiumsolute symport family (SSF, [5]). Unfortunately, detailed biophysical and biochemical studies with STP-like transporters in respect to structure-function research, transport cycle, and the associated conformational change vanished in the 90th of the last century. In contrast, SGLT1 and LacY were intensively studied using the cysteine scanning mutagenesis approach in combination with functional studies to draw a mechanistic model of cation-coupled substrate transport across membranes (e.g., [2, 29, 37, 57, 79-81, 86, 146, 184]). Thereby, TM helices and/or individual amino acid residues were identified that contribute to sugar binding/ selectivity that are accessible for functional fluorescent molecules such as tetramethyl-rhodamine-6-maleimide (TMRM6) or positions that lead to unfunctional SGLT/LacY mutants following the binding of -SH reagents to the introduced cysteine.

Site-directed alkylation and fluorescence-based methods, as well as single-molecule fluorescence resonance energy transfer (smFRET), support a six-state alternating access model, in which a conformational change is necessary for completion of the LacY transport catalysis [51, 86, 146]. In the case of the electrogenic SGLT1, electrophysiological measurements were combined with voltage-clamp fluorometry (VCF) in Xenopus laevis oocytes [79-81, 88]. Thereby, sitespecific labeling of an introduced Cys residue with environmentally sensitive fluorophores enabled real-time observation of intramolecular movements under various conditions and positions (e.g., Q457 and G507) in the protein. These fluorescence studies of ligand-induced conformational changes in conjunction with pre-steady-state current analysis associated the charge movements (revealed from $\mathrm{I}_{\text {pre }}$ ) with conformational changes of the sodium/glucose cotransporter. When SGLT1 was labelled at position 457, both the level and time course of the change in fluorescence (indicating movements of the specific protein domain) closely followed the charge movements that are a hallmark of the voltage-induced changes in state of the protein [79]. With SGLT1 labelled at position 507, the authors uncovered another slow conformational change probably due to a slow electroneutral step in the transport cycle associated with the release of sodium at the internal membrane surface [80]. Based on many studies using combinations of sophisticated electrophysiological and fluorescence-based techniques, an essential six-state reaction scheme with alternating access of the substrate binding sites for SGLT1 was proposed-similar to the situation in $\operatorname{LacY}[38,59,79-81$, 107, 146].

Thus, VCF measurements represent a sophisticated technique to dissect the transport cycle of transporter proteins in partial reactions involved, e.g., in sugar binding and translocation. Neundlinger et al. could add further data in respect to glucose/inhibitor binding to SGLT1 in its natural environment 
using single-molecule force spectroscopy [99]. The authors resolved the forces and dynamics of glucose/inhibitor binding on the single-molecule level indicating that sugar translocation involves several steps with different temperature sensitivities.

Plant STP transporters were not studied in respect to conformational changes using VCF or similar techniques and thus data concerning transport-associated movements of the protein are not available. The only plant sugar transporter studied with VCF is ZmSUT1 - a proton-coupled sucrose transporter originating from a distinct subfamily of the major facilitator superfamily (MFS) - the glycoside-pentoside-hexuronide $(\mathrm{GPH})$ cation symporter family [27, 125] (Fig. 2a).

\section{Structure of cation-coupled transporters from the MFS family}

Today, the MFS superfamily includes millions of sequenced members distributed ubiquitously across all three kingdoms of life that transport a diverse variety of substrates in either uniport, symport, or antiport ([72, 105, 125, 182]; http:// www.tcdb.org/). Until lately, information about the structure of plant sugar transporters was limited to sequence homologies to bacterial and animal cation-coupled transporters. These homologies with non-plant transporters supported the membership of plant hexose transporters in the major facilitator superfamily $[105,125]$. In line with members of the MFS, hydropathy analyses with plant monosaccharide transporter sequences predicted 12 transmembrane helices with the $\mathrm{N}$ - and $\mathrm{C}$-terminus located in the cytosol for the analyzed proteins (e.g., [119, 129]). Crystal structures of LacY (lactose $/ \mathrm{H}^{+}$permease from E. coli) and other MFS transporters elucidated the three-dimensional organization of this type of transporters ([2,5] and references therein). It could be shown that these transporters consist of two pseudo-

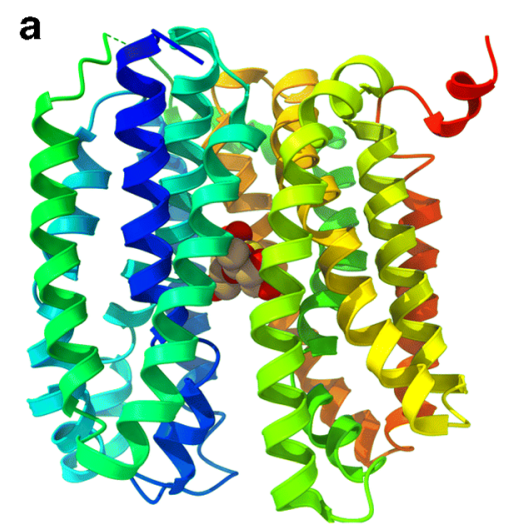

Fig. 5 Alternating access model illustrated with the LacY structure. a Outward facing (accession number 4OAA) and b inward-facing (accession number 2 Y $5 Y$ ) structure of LacY. Structures are downloaded from PDB (www.pdb.org) and presented using UCSF symmetrical halves formed by six TMD (transmembrane domains) bundles each, which are connected by an extended cytoplasmic loop. The sugar-binding site at the interface of the two halves is placed in the middle of the membrane. Biochemical and biophysical data resolved irreplaceable and highly conserved amino acid residues involved in substrate binding and proton transduction [58]. In high-resolution Xray structures of LacY, a large internal cavity is open towards the cytoplasm but closed to the periplasm, representing the inward-facing conformation of the transporter [1, 42, 43]. Using double Gly-to-Trp mutants to introduce bulky side chains on the periplasmic side between the $\mathrm{N}$ - and $\mathrm{C}$ terminal sixhelical halves of LacY [145] and later on with the help of nanobodies, the periplasmic-open conformation and transient conformers of LacY could be stabilized and crystalized [52, 69, 143, 144]. Thus, X-ray structures of LacY provide snapshots of local and global conformational changes that allow the sugar- and proton-binding sites gain alternating access to either side of the membrane (Fig. 5). These observations are underpinned by pre-steady-state kinetic analysis and multiple biochemical as well as spectroscopic approaches that-together with the structural data - document the alternating access mechanism underlying the symport of $\mathrm{H}^{+}$and sugar in LacY (Fig. 5).

Based on these extensive studies and the high-resolution crystal structures, the LacY transporter often served as a template for 3D structural models of related transporters to predict tertiary structures and functional domains [40, 46, 108, 112, $166,172,187]$. Sequence alignments and modelling attempts between LacY and plant sugar transporters showed only low sequence identities and only few of the essential amino acid site chains of LacY are present at identical positions in the respective TMDs of the plant counterparts. Thus, 3D modeling of plant sugar transporters may predict the overall tertiary structure only and will not explain the mechanism of highaffinity substrate transport in, e.g., STPs.

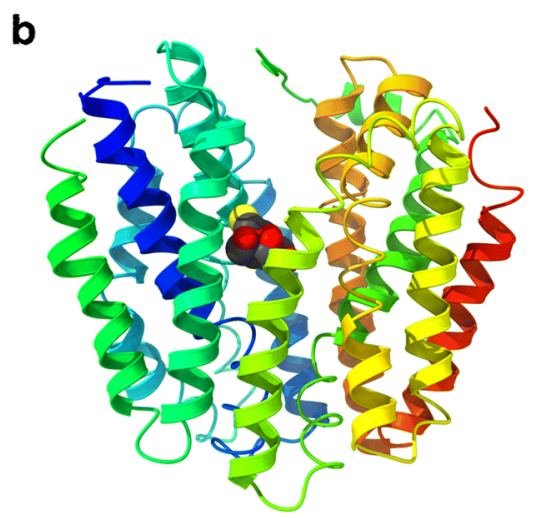

ChimeraX (http://www.rbvi.ucsf.edu/chimerax, version 0.94). The helices were colored using rainbow from $\mathrm{N}$ (blue) to $\mathrm{C}$ terminus (red). Bound sugars are shown as spheres. The cytoplasmic surface is at the top 
Very recently, Paulsen and co-workers determined the crystal structure of AtSTP10 in an outward facing occluded state with glucose bound in a central binding site at a resolution of $2.4 \AA$ [109]. Just like AtSTP1, the pollen tubeexpressed AtSTP10 represents a typical proton-driven symporter that besides glucose transports galactose and mannose with high affinity (low $\mu \mathrm{M}$ range, Table 1) [124]. The overall fold of AtSTP10 is reminiscent of the typical major facilitator structure with 12 TMDs divided into two pseudosymmetrical halves each consisting of six TM helices and a central sugar binding site located between the $\mathrm{N}$ - and $\mathrm{C}$ terminal domains [109] (Fig. 6). Besides the common basic structural organization shared between the members of the MFS, the crystal structure of AtSTP10 revealed an unexpected feature: a "helix-helix-loop-helix" domain in the first extracellular loop between TMD1 and 2 that covers the entry pathway of sugars and was thus named "Lid" domain. This protrusion of the loop between TMD1-2 is covalently linked to the Cterminal domain by a disulfide bridge locking the $\mathrm{N}$ - and $\mathrm{C}$ terminal domains together (Fig. 6). Due to the position of the Lid domain, there is no clear entry pathway for the substrate as seen in other major facilitators [26]. Interestingly, the Lid domain resembles a conserved feature found in sequences of all STPs and was thus far not found in any other member of the MFS.

How to explain the high affinity of STP transporters? Based on the crystal structure of AtSTP10, the authors found close interactions of glucose with three residues in the Nterminal domain (Phe39, Ile184, and Leu43) that create a hydrophobic interaction surface for the sugar. This tight and hydrophobic interaction surface cannot be found in lowaffinity human GLUTs or bacterial sugar $/ \mathrm{H}^{+}$transporters, where the distance is longer and the interacting residues are polar $[26,48,155]$. High-affinity protein-ligand and proteinprotein interactions seem to be based on tight hydrophobic interaction interfaces $[60,147]$ indicating that the highaffinity transport via STPs results from the tight binding of glucose to the identified hydrophobic interaction surface [109].

Below the Lid domain, only two charged residues (Asp42 and Arg142) were found in the TMD region that could act as proton donor/acceptor pair needed for proton translocation and the coupling between cation $\left(\mathrm{H}^{+}\right)$and sugar transport [14]. The position within the structure is similar to the respective position of other proton-coupled transporters of the MFS $[48,171]$ and mutants of AtSTP10 at positions Asp42 and Arg 142 did not transport glucose anymore [109]. The authors suggest that protonation at Asp42 leads to a displacement of Arg 142 and thus a movement of the outer part of TMD1. This involves the movement of the glucose interaction sites Phe39 and Leu43, which subsequently leads to the tight coordination of the substrate. This scenario provides an explanation for the tight coupling of the proton-motive force and the transport of sugar. Due to the lack of structural information about the inward facing conformation of AtSTP10, the mechanism of sugar $/ \mathrm{H}^{+}$release and the accompanying conformational change remain to be elucidated.

Why does STPs possess a Lid domain? Based on their structural and functional findings, Paulsen et al. propose that the Lid domain via the disulfide bridge locks the N- and Cterminal six-helix bundles together (see Fig. 6) and that a conformational change must occur to allow the entry of the substrate to the binding site in the middle of the TMDs. The Lid isolates the proton donor/acceptor pair as well as the a

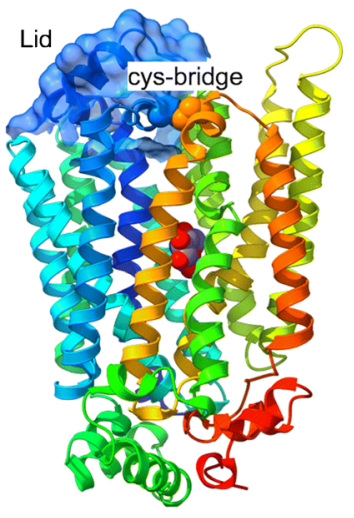

side view

Fig. 6 A structural perspective of the Arabidopsis thaliana monosaccharide transporter AtSTP10 from side (a) and top (b) perspective. The structure represents an outward facing occluded state of the sugar transporter in complex with glucose (shown as spheres). Structure (accession number 6H7D) is downloaded from PDB (www. pdb.org) and presented using UCSF ChimeraX (http://www.rbvi.ucsf.

b

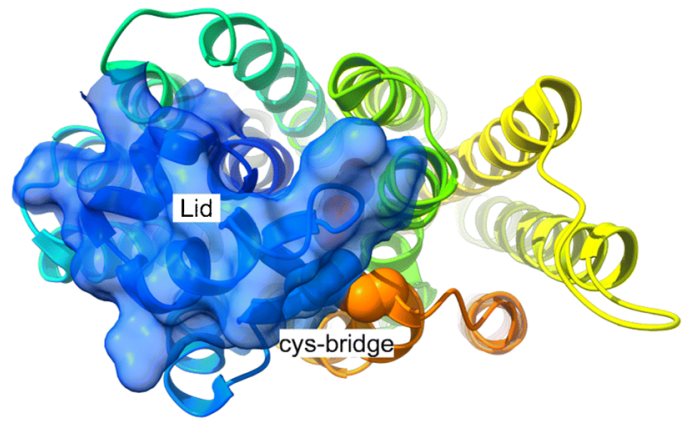

Top view

edu/chimerax, version 0.94). The helices were colored using rainbow from $\mathrm{N}$ (blue) to $\mathrm{C}$ terminus (red). The surface of the STP-specific helix-helix-loop-helix motif (Lid) in the loop between TMD1-2 is illustrated in transparent blue. The cysteins involved in the disulfide bridge locking the $\mathrm{N}$ - and $\mathrm{C}$-terminal domains together are shown as blue (Cys77) and orange (Cys449) spheres 
sugar-binding site from the extracellular environment and thereby creates a local milieu for efficient transport of glucose at physiological $\mathrm{pH}$ values of around $\mathrm{pH} 5$ to 6 . Respective mutants that do not possess a disulfide bridge between the Lid domain and the $\mathrm{C}$-terminal domain displayed a $\mathrm{pH}$ optimum for transport of glucose that was markedly shifted to more acidic $\mathrm{pH}$ values.

In contrast to MFS members, SGLTs group into the large family of solute sodium symporters (SSS) $[175,176]$ that cotransport $\mathrm{Na}^{+}$with sugars or in the case of SGLT3 act as glucose sensor $[28,130]$. The physiological roles and the human diseases related to the disfunction of SGLT family members have been well characterized (detailed summaries of the pathophysiology of the SGLT family is the topic of other reviews within this issue). SGLTs share an alternating-access mechanism with tight coupling between $\mathrm{Na}^{+}$and sugar transport $[80,83]$.

In 2008/2010, Faham et al. and Watanabe et al., respectively, $[32,168]$ could resolve the crystal structure of the Vibrio parahaemolyticus $\mathrm{Na}^{+}$/galactose symporter (vSGLT) with $3.0 \AA$ in the inward-facing occluded and the inward-facing open state. Experimental and in silico studies predicted 14 TMDs with extracellular amino and carboxy termini for SGLT1, which was finally confirmed by the crystal structure of vSGLT $[162,163]$. The core structure consists of inverted repeats of 5 TMDs (TM2 to TM6 and TM7 to TM11) and galactose is bound in the center of the N-terminal and Cterminal 5 TMD bundles, occluded from the outside solutions by hydrophobic residues. Thus, despite of the similarity of the overall fold that is shared between vSGLT and LeuT $(5+5)$ fold transporters (cf. [5]), vSGLT has its own specific structural modifications: vSGLT contains 14 TMDs and extracellular amino- and carboxyl-termini [32, 168]. Interestingly, the core structure of vSGLT is similar to the leucine transporter (LeuT) originating from a different gene family $[67,180]$. This similarity, the vast amount of biophysical data of studies with SGLTs [99, 175], and the well-characterized structures of LeuT were sufficient to model the outward-facing confirmation of vSGLT and to predict sodium and sugar-binding sites as well as the structural movements accompanying the transport of $\mathrm{Na}^{+} /$sugars via SGLTs $[32,168]$.

Thus, having the structures from the plant AtSTP10 and its bacterial/animal counterpart in hands, it becomes clear that there are similarities but also pronounced differences among the different transporter families. These information could now help to perform detailed structure-function analysis to better understand the high-affinity transport mechanism of plant MSTs of the STP family.

\section{Future opportunities}

Pronounced progress in identifying, characterizing, and determining plant sugar transporters has been made within the last decades. However, in comparison to the deep biophysical, biochemical, and structural characterization of bacterial and animal model transporters, the plant functional orthologs have been studied in less detail so far. The high impact of basic research on bacterial and animal transport proteins, such as LacY, LeuT, SGLT, and GLUT, results at least in part from the incitement to understand the transport mechanisms in molecular/atomic detail to develop medications to cure diseases related to those transporters or transported substances. As sessil organisms, plants synthesize high numbers of various secondary metabolites; thus, plant transport proteins seem to be less sensitive to chemicals (agonists/antagonists/inhibitors) or alternatively, the pharmacology of plant transport proteins was not sufficiently tested so far. The incitement of the agricultural industry, funding agencies, and basic research at universities to understand plant transport proteins on the atomic level and subsequently to manipulate or protect crops from diseases seems to be less developed than the interest in animal/ bacterial transporters.

With the first X-ray structure of a plant sugar transporter in hands (AtSTP10; [109]), the door is now open to combine biochemical and biophysical studies to understand the molecular mechanism of monosaccharide transport in plants. Therefore, further structural information about AtSTP10 in different conformations needs to be obtained to gain highresolution snapshots of individual steps in its reaction cycle. These structural data have to be complemented with dynamic information about how sugar, protons, and the membrane potential induces local or global conformational changes and to understand the tight coupling between the proton motive force to the transport of sugar.

These studies have to include, e.g., site-directed mutagenesis, sophisticated electrophysiology, structural biology, molecular dynamics simulations, and fluorescencebased techniques to dissect the transport cycle of STP10 into individual steps. Thereby, the research on bacterial and animal transporters can guide the studies with plant transporters. The comparison of structural and functional features of different transporters will finally reveal fundamental principles of sugar transport with similarities and distinctions that (co-)evolved driven by specific challenges during the evolution of transport proteins in the three kingdoms of life.

Acknowledgments The author thanks the Deutsche Forschungsgemeinschaft (DFG) for grants within the project GE2195/ 1-1 and Dorothea Graus for illustrating figures 1, 3, and 4.

\section{Author's contributions N/A}

Funding information Open Access funding enabled and organized by Projekt DEAL. This study was supported by the Deutsche Forschungsgemeinschaft (DFG) for grants within the project GE2195/1-1. 
Data availability N/A

\section{Compliance with ethical standards}

Conflict of interest The author declares that he has no conflicts of interest.

\section{Ethics approval N/A}

Consent to participate N/A

Consent for publication N/A

\section{Code availability N/A}

Open Access This article is licensed under a Creative Commons Attribution 4.0 International License, which permits use, sharing, adaptation, distribution and reproduction in any medium or format, as long as you give appropriate credit to the original author(s) and the source, provide a link to the Creative Commons licence, and indicate if changes were made. The images or other third party material in this article are included in the article's Creative Commons licence, unless indicated otherwise in a credit line to the material. If material is not included in the article's Creative Commons licence and your intended use is not permitted by statutory regulation or exceeds the permitted use, you will need to obtain permission directly from the copyright holder. To view a copy of this licence, visit http://creativecommons.org/licenses/by/4.0/.

\section{References}

1. Abramson J, Smirnova I, Kasho V, Verner G, Kaback HR, Iwata S (2003) Structure and mechanism of the lactose permease of Escherichia coli. Science 301:610-615. https://doi.org/10.1126/ science. 1088196

2. Abramson J, Iwata S, Kaback HR (2004) Lactose permease as a paradigm for membrane transport proteins (Review). Mol Membr Biol 21:227-236. https://doi.org/10.1080/ 09687680410001716862

3. Afoufa-Bastien D, Medici A, Jeauffre J, Coutos-Thevenot P, Lemoine R, Atanassova R, Laloi M (2010) The Vitis vinifera sugar transporter gene family: phylogenetic overview and macroarray expression profiling. BMC Plant Biol 10:245. https://doi.org/10.1186/1471-2229-10-245

4. Aoshima H, Yamada M, Sauer N, Komor E, Schobert C (1993) Heterologous expression of the $\mathrm{H}+/$ Hexose cotransporter from chlorella in Xenopus oocytes and its characterization with respect to sugar specificity, $\mathrm{pH}$ and membrane-potential. J Plant Physiol 141:293-297. https://doi.org/10.1016/S0176-1617(11)81737-2

5. Bai X, Moraes TF, Reithmeier RAF (2017) Structural biology of solute carrier (SLC) membrane transport proteins. Mol Membr Biol 34:1-32. https://doi.org/10.1080/09687688.2018.1448123

6. Baier M, Hemmann G, Holman R, Corke F, Card R, Smith C, Rook F, Bevan MW (2004) Characterization of mutants in Arabidopsis showing increased sugar-specific gene expression, growth, and developmental responses. Plant Physiol 134:81-91. https://doi.org/10.1104/pp.103.031674

7. Bechtold U, Rabbani N, Mullineaux PM, Thornalley PJ (2009) Quantitative measurement of specific biomarkers for protein oxidation, nitration and glycation in Arabidopsis leaves. Plant J 59: 661-671. https://doi.org/10.1111/j.1365-313X.2009.03898.x
8. Beyenbach KW, Wieczorek H (2006) The V-type H+ ATPase: molecular structure and function, physiological roles and regulation. J Exp Biol 209:577-589. https://doi.org/10.1242/jeb.02014

9. Bezrutczyk M, Yang JI, Eom JS, Prior M, Sosso D, Hartwig T, Szurek B, Oliva R, Vera-Cruz C, White FF, Yang B, Frommer WB (2018) Sugar flux and signaling in plant-microbe interactions. Plant J 93:675-685. https://doi.org/10.1111/tpj.13775

10. Boller T, Wiemken A (1986) Dynamics of vacuolar compartmentation. Annu Rev Plant Physiol 3:137-164

11. Boorer KJ, Forde BG, Leigh RA, Miller AJ (1992) Functional expression of a plant plasma membrane transporter in Xenopus oocytes. FEBS Lett 302:166-168. https://doi.org/10.1016/00145793(92)80431-f

12. Boorer KJ, Loo DD, Wright EM (1994) Steady-state and presteady-state kinetics of the $\mathrm{H}+$ /hexose cotransporter (STP1) from Arabidopsis thaliana expressed in Xenopus oocytes. J Biol Chem 269:20417-20424

13. Bossi E, Centinaio E, Castagna M, Giovannardi S, Vincenti S, Sacchi VF, Peres A (1999) Ion binding and permeation through the lepidopteran amino acid transporter KAAT1 expressed in Xenopus oocytes. J Physiol Lond 515:729-742. https://oi.org/ 10.1111/j.1469-7793.1999.729ab.x

14. Buch-Pedersen MJ, Pedersen BP, Veierskov B, Nissen P, Palmgren MG (2009) Protons and how they are transported by proton pumps. Pflugers Arch - Eur J Physiol 457:573-579. https:// doi.org/10.1007/s00424-008-0503-8

15. Burkle L, Hibberd JM, Quick WP, Kuhn C, Hirner B, Frommer WB (1998) The H+-sucrose cotransporter NtSUT1 is essential for sugar export from tobacco leaves. Plant Physiol 118:59-68. https://doi.org/10.1104/pp.118.1.59

16. Buttner M (2007) The monosaccharide transporter(-like) gene family in Arabidopsis. FEBS Lett 581:2318-2324. https://doi. org/10.1016/j.febslet.2007.03.016

17. Buttner M (2010) The Arabidopsis sugar transporter (AtSTP) family: an update. Plant Biol (Stuttg) 12(Suppl 1):35-41. https://doi. org/10.1111/j.1438-8677.2010.00383.x

18. Buttner M, Sauer N (2000) Monosaccharide transporters in plants: structure, function and physiology. Biochim Biophys Acta 1465: 263-274. https://doi.org/10.1016/s0005-2736(00)00143-7

19. Büttner M, Truernit E, Baier K, Scholz-Starke J, Sontheim M, Lauterbach C, Huss VAR, Sauer N (2000) AtSTP3, a green leafspecific, low affinity monosaccharide-H+ symporter of Arabidopsis thaliana. Plant Cell Environ 23:175-184. https://doi. org/10.1046/j.1365-3040.2000.00538.x

20. Carpaneto A, Geiger D, Bamberg E, Sauer N, Fromm J, Hedrich R (2005) Phloem-localized, proton-coupled sucrose carrier ZmSUT1 mediates sucrose efflux under the control of the sucrose gradient and the proton motive force. J Biol Chem 280:2143721443. https://doi.org/10.1074/jbc.M501785200

21. Carpaneto A, Koepsell H, Bamberg E, Hedrich R, Geiger D (2010) Sucrose- and H+-dependent charge movements associated with the gating of sucrose transporter ZmSUT1. PLoS One 5: ARTN e12605. https://doi.org/10.1371/journal.pone.0012605

22. Caspari T, Will A, Opekarova M, Sauer N, Tanner W (1994) Hexose $/ \mathrm{H}+$ symporters in lower and higher-plants. J Exp Biol 196:483-491

23. Chen LQ, Hou BH, Lalonde S, Takanaga H, Hartung ML, Qu XQ, Guo WJ, Kim JG, Underwood W, Chaudhuri B, Chermak D, Antony G, White FF, Somerville SC, Mudgett MB, Frommer WB (2010) Sugar transporters for intercellular exchange and nutrition of pathogens. Nature 468:527-532. https://doi.org/10.1038/ nature 09606

24. Cordoba E, Aceves-Zamudio DL, Hernandez-Bernal AF, RamosVega M, Leon P (2015) Sugar regulation of sugar transporter protein 1 (STP1) expression in Arabidopsis thaliana. J Exp Bot 66:147-159. https://doi.org/10.1093/jxb/eru394 
25. Danaei G, Finucane MM, Lu Y, Singh GM, Cowan MJ, Paciorek CJ, Lin JK, Farzadfar F, Khang Y-H, Stevens GA, Rao M, Ali MK, Riley LM, Robinson CA, Ezzati M (2011) National, regional, and global trends in fasting plasma glucose and diabetes prevalence since 1980: systematic analysis of health examination surveys and epidemiological studies with 370 country-years and 2\&\#xb7;7 million participants. Lancet 378:31-40. https://doi. org/10.1016/S0140-6736(11)60679-X

26. Deng D, Sun PC, Yan CY, Ke M, Jiang X, Xiong L, Ren WL, Hirata K, Yamamoto M, Fan SL, Yan N (2015) Molecular basis of ligand recognition and transport by glucose transporters. Nature 526:391. https://doi.org/10.1038/nature14655

27. Derrer C, Wittek A, Bamberg E, Carpaneto A, Dreyer I, Geiger D (2013) Conformational changes represent the rate-limiting step in the transport cycle of maize sucrose transporter1. Plant Cell 25: 3010-3021. https://doi.org/10.1105/tpc.113.113621

28. Diez-Sampedro A, Wright EM, Hirayama BA (2001) Residue 457 controls sugar binding and transport in the $\mathrm{Na}(+) /$ glucose cotransporter. J Biol Chem 276:49188-49194. https://doi.org/10. 1074/jbc.M108286200

29. Diez-Sampedro A, Hirayama BA, Osswald C, Gorboulev V, Baumgarten K, Volk C, Wright EM, Koepsell H (2003) A glucose sensor hiding in a family of transporters. Proc Natl Acad Sci U S A 100:11753-11758. https://doi.org/10.1073/pnas.1733027100

30. Doidy J, Grace E, Kuhn C, Simon-Plas F, Casieri L, Wipf D (2012) Sugar transporters in plants and in their interactions with fungi. Trends Plant Sci 17:413-422. https://doi.org/10.1016/j. tplants.2012.03.009

31. Eskandari S, Wright EM, Loo DDF (2005) Kinetics of the reverse mode of the Na+/glucose cotransporter. J Membr Biol 204:23-32. https://doi.org/10.1007/s00232-005-0743-x

32. Faham S, Watanabe A, Besserer GM, Cascio D, Specht A, Hirayama BA, Wright EM, Abramson J (2008) The crystal structure of a sodium galactose transporter reveals mechanistic insights into $\mathrm{Na}(+) /$ sugar symport. Science 321:810-814. https://doi.org/ 10.1126/science. 1160406

33. Falhof J, Pedersen JT, Fuglsang AT, Palmgren M (2016) Plasma membrane $\mathrm{H}(+)$-ATPase regulation in the center of plant physiology. Mol Plant 9:323-337. https://doi.org/10.1016/j.molp.2015. 11.002

34. Fisher SA, Burggren WW (2007) Role of hypoxia in the evolution and development of the cardiovascular system. Antioxid Redox Signal 9:1339-1352. https://doi.org/10.1089/ars.2007.1704

35. Flutsch S, Nigro A, Conci F, Fajkus J, Thalmann M, Trtilek M, Panzarova K, Santelia D (2020) Glucose uptake to guard cells via STP transporters provides carbon sources for stomatal opening and plant growth. EMBO Rep e49719. https://doi.org/10.15252/ embr.201949719

36. Fotopoulos V, Gilbert MJ, Pittman JK, Marvier AC, Buchanan AJ, Sauer N, Hall JL, Williams LE (2003) The monosaccharide transporter gene, AtSTP4, and the cell-wall invertase, Atbetafruct1, are induced in Arabidopsis during infection with the fungal biotroph Erysiphe cichoracearum. Plant Physiol 132: 821-829. https://doi.org/10.1104/pp.103.021428

37. Frillingos S, Sahin-Toth M, Wu J, Kaback HR (1998) Cysscanning mutagenesis: a novel approach to structure function relationships in polytopic membrane proteins. FASEB J 12:12811299. https://doi.org/10.1096/fasebj.12.13.1281

38. Gagnon DG, Frindel C, Lapointe JY (2007) Voltage-clamp fluorometry in the local environment of the C255-C511 disulfide bridge of the Na+/glucose cotransporter. Biophys J 92:24032411. https://doi.org/10.1529/biophysj.106.097964

39. Gahrtz M, Stolz J, Sauer N (1994) A phloem-specific sucrose-H+ symporter from Plantago-Major L supports the model of apoplastic phloem loading. Plant J 6:697-706. https://doi.org/10. 1046/j.1365-313X.1994.6050697.x
40. Gottschalk KE, Soskine M, Schuldiner S, Kessler H (2004) A structural model of EmrE, a multi-drug transporter from Escherichia coli. Biophys J 86:3335-3348. https://doi.org/10. 1529/biophysj.103.034546

41. Gottwald JR, Krysan PJ, Young JC, Evert RF, Sussman MR (2000) Genetic evidence for the in planta role of phloem-specific plasma membrane sucrose transporters. Proc Natl Acad Sci U S A 97:13979-13984. https://doi.org/10.1073/pnas.250473797

42. Guan L, Kaback HR (2007) Site-directed alkylation of cysteine to test solvent accessibility of membrane proteins. Nat Protoc 2: 2012-2017. https://doi.org/10.1038/nprot.2007.275

43. Guan L, Mirza O, Verner G, Iwata S, Kaback HR (2007) Structural determination of wild-type lactose permease. Proc Natl Acad Sci U S A 104:15294-15298. https://doi.org/10.1073/ pnas.0707688104

44. Haass D, Tanner W (1974) Regulation of hexose transport in Chlorella vulgaris: characteristics of induction and turnover. Plant Physiol 53:14-20. https://doi.org/10.1104/pp.53.1.14

45. Hilgemann DW, Lu CC (1999) GAT1 (GABA : Na+: Cl-) cotransport function - database reconstruction with an alternating access model. J Gen Physiol 114:459-475. https://doi.org/10. 1085/jgp.114.3.459

46. Hirai T, Heymann JA, Shi D, Sarker R, Maloney PC, Subramaniam S (2002) Three-dimensional structure of a bacterial oxalate transporter. Nat Struct Biol 9:597-600. https://doi.org/10. 1038/nsb821

47. Hirsch RE, Lewis BD, Spalding EP, Sussman MR (1998) A role for the AKT1 potassium channel in plant nutrition. Science 280: 918-921. https://doi.org/10.1126/science.280.5365.918

48. Iancu CV, Zamoon J, Woo SB, Aleshin A, Choe JY (2013) Crystal structure of a glucose/H+ symporter and its mechanism of action. Proc Natl Acad Sci U S A 110:17862-17867. https:// doi.org/10.1073/pnas.1311485110

49. Jaitovich AA, Bertorello AM (2006) Na+, K+ -ATPase: an indispensable ion pumping-signaling mechanism across mammalian cell membranes. Semin Nephrol 26:386-392. https://doi.org/10. 1016/j.semnephrol.2006.07.002

50. Jang JC, Leon P, Zhou L, Sheen J (1997) Hexokinase as a sugar sensor in higher plants. Plant Cell 9:5-19. https://doi.org/10.1105/ tpc.9.1.5

51. Jiang X, Nie Y, Kaback HR (2011) Site-directed alkylation studies with LacY provide evidence for the alternating access model of transport. Biochemistry-Us 50:1634-1640. https://doi.org/10. 1021/bi101988s

52. Jiang X, Smirnova I, Kasho V, Wu J, Hirata K, Ke M, Pardon E, Steyaert J, Yan N, Kaback HR (2016) Crystal structure of a LacYnanobody complex in a periplasmic-open conformation. Proc Natl Acad Sci U S A 113:12420-12425. https://doi.org/10.1073/pnas. 1615414113

53. Johnson DA, Thomas MA (2007) The monosaccharide transporter gene family in Arabidopsis and rice: a history of duplications, adaptive evolution, and functional divergence. Mol Biol Evol 24: 2412-2423. https://doi.org/10.1093/molbev/msm184

54. Johnson DA, Hill JP, Thomas MA (2006) The monosaccharide transporter gene family in land plants is ancient and shows differential subfamily expression and expansion across lineages. BMC Evol Biol 6:64. https://doi.org/10.1186/1471-2148-6-64

55. Julius BT, Leach KA, Tran TM, Mertz RA, Braun DM (2017) Sugar transporters in plants: new insights and discoveries. Plant Cell Physiol 58:1442-1460. https://doi.org/10.1093/pcp/pcx090

56. Kaback HR (1997) A molecular mechanism for energy coupling in a membrane transport protein, the lactose permease of Escherichia coli. Proc Natl Acad Sci U S A 94:5539-5543. https://doi.org/10.1073/pnas.94.11.5539 
57. Kaback HR, Sahin-Toth M, Weinglass AB (2001) The kamikaze approach to membrane transport. Nat Rev Mol Cell Biol 2:610 620. https://doi.org/10.1038/35085077

58. Kaback HR, Dunten R, Frillingos S, Venkatesan P, Kwaw I, Zhang W, Ermolova N (2007) Site-directed alkylation and the alternating access model for LacY. Proc Natl Acad Sci U S A 104:491-494. https://doi.org/10.1073/pnas.0609968104

59. Kaback HR, Smirnova I, Kasho V, Nie Y, Zhou Y (2011) The alternating access transport mechanism in LacY. J Membr Biol 239:85-93. https://doi.org/10.1007/s00232-010-9327-5

60. Kastritis PL, Bonvin AMJJ (2013) On the binding affinity of macromolecular interactions: daring to ask why proteins interact. J R Soc Interface 10:ARTN 20120835. https://doi.org/10.1098/rsif. 2012.0835

61. Knoblauch M, Knoblauch J, Mullendore DL, Savage JA, Babst BA, Beecher SD, Dodgen AC, Jensen KH, Holbrook NM (2016) Testing the Munch hypothesis of long distance phloem transport in plants. Elife 5. https://doi.org/10.7554/eLife.15341

62. Komor E (1973) Proton-coupled hexose transport in Chlorella vulgaris. FEBS Lett 38:16-18. https://doi.org/10.1016/00145793(73)80501-0

63. Komor E, Tanner W (1974) The hexose-proton cotransport system of chlorella. $\mathrm{pH}$-dependent change in Km values and translocation constants of the uptake system. J Gen Physiol 64:568-581. https://doi.org/10.1085/jgp.64.5.568

64. Komor E, Tanner W (1974) The hexose-proton symport system of Chlorella vulgaris. Specificity, stoichiometry and energetics of sugar-induced proton uptake. Eur J Biochem 44:219-223. https://doi.org/10.1111/j.1432-1033.1974.tb03476.x

65. Komor E, Tanner W (1976) The determination of the membrane ptoential of Chlorella vulgaris. Evidence for electrogenic sugar transport. Eur J Biochem 70:197-204. https://doi.org/10.1111/j. 1432-1033.1976.tb10970.x

66. Komor E, Haass D, Komor B, Tanner W (1973) Active hexoseuptake system of Chlorella-Vulgaris-Km-Values for 6deoxyglucose influx and efflux and their contribution to sugar accumulation. Eur J Biochem 39:193-200. https://doi.org/10. 1111/j.1432-1033.1973.tb03117.x

67. Krishnamurthy H, Gouaux E (2012) X-ray structures of LeuT in substrate-free outward-open and apo inward-open states. Nature 481:469-474. https://doi.org/10.1038/nature10737

68. Kuhn C, Franceschi VR, Schulz A, Lemoine R, Frommer WB (1997) Macromolecular trafficking indicated by localization and turnover of sucrose transporters in enucleate sieve elements. Science 275:1298-1300. https://doi.org/10.1126/science.275. 5304.1298

69. Kumar H, Finer-Moore JS, Jiang X, Smirnova I, Kasho V, Pardon E, Steyaert J, Kaback HR, Stroud RM (2018) Crystal Structure of a ligand-bound LacY-Nanobody Complex. Proc Natl Acad Sci U S A 115:8769-8774. https://doi.org/10.1073/pnas.1801774115

70. LaBarbera M (1990) Principles of design of fluid transport systems in zoology. Science 249:992-1000. https://doi.org/10.1126/ science. 2396104

71. Lang D, Weiche B, Timmerhaus G, Richardt S, Riano-Pachon DM, Correa LG, Reski R, Mueller-Roeber B, Rensing SA (2010) Genome-wide phylogenetic comparative analysis of plant transcriptional regulation: a timeline of loss, gain, expansion, and correlation with complexity. Genome Biol Evol 2:488-503. https://doi.org/10.1093/gbe/evq032

72. Law CJ, Maloney PC, Wang DN (2008) Ins and outs of major facilitator superfamily antiporters. Annu Rev Microbiol 62:289305. https://doi.org/10.1146/annurev.micro.61.080706.093329

73. Lemoine R, La Camera S, Atanassova R, Dedaldechamp F, Allario T, Pourtau N, Bonnemain JL, Laloi M, Coutos-Thevenot P, Maurousset L, Faucher M, Girousse C, Lemonnier P, Parrilla J, Durand M (2013) Source-to-sink transport of sugar and regulation by environmental factors. Front Plant Sci 4:272. https://oi.org/ 10.3389/fpls.2013.00272

74. Lemonnier P, Gaillard C, Veillet F, Verbeke J, Lemoine R, Coutos-Thevenot P, La Camera S (2014) Expression of Arabidopsis sugar transport protein STP13 differentially affects glucose transport activity and basal resistance to Botrytis cinerea. Plant Mol Biol 85:473-484. https://doi.org/10.1007/s11103-0140198-5

75. Ligrone R, Ducket JG, Renzaglia KS (2000) Conducting tissues and phyletic relationships of bryophytes. Philos Trans R Soc Lond Ser B Biol Sci 355:795-813. https://doi.org/10.1098/rstb.2000. 0616

76. Ligrone R, Duckett JG, Renzaglia KS (2012) Major transitions in the evolution of early land plants: a bryological perspective. Ann Bot 109:851-871. https://doi.org/10.1093/aob/mcs017

77. Livingston DP, Henson CA (1998) Apoplastic sugars, fructans, fructan exohydrolase, and invertase in winter oat: responses to second-phase cold hardening. Plant Physiol 116:403-408. https://doi.org/10.1104/pp.116.1.403

78. Lohaus G, Hussmann M, Pennewiss K, Schneider H, Zhu JJ, Sattelmacher B (2000) Solute balance of a maize (Zea mays L.) source leaf as affected by salt treatment with special emphasis on phloem retranslocation and ion leaching. J Exp Bot 51:17211732. https://doi.org/10.1093/jexbot/51.351.1721

79. Loo DDF, Hazama A, Supplisson S, Turk E, Wright EM (1993) Relaxation kinetics of the Na+/glucose cotransporter. Proc Natl Acad Sci U S A 90:5767-5771. https://doi.org/10.1073/pnas.90. 12.5767

80. Loo DD, Hirayama BA, Gallardo EM, Lam JT, Turk E, Wright EM (1998) Conformational changes couple $\mathrm{Na}+$ and glucose transport. Proc Natl Acad Sci U S A 95:7789-7794. https://doi. org/10.1073/pnas.95.13.7789

81. Loo DD, Hirayama BA, Karakossian MH, Meinild AK, Wright EM (2006) Conformational dynamics of hSGLT1 during Na+/ glucose cotransport. J Gen Physiol 128:701-720. https://doi.org/ 10.1085/jgp.200609643

82. Lucas WJ, Groover A, Lichtenberger R, Furuta K, Yadav SR, Helariutta Y, He XQ, Fukuda H, Kang J, Brady SM, Patrick JW, Sperry J, Yoshida A, Lopez-Millan AF, Grusak MA, Kachroo P (2013) The plant vascular system: evolution, development and functions. J Integr Plant Biol 55:294-388. https://doi. org/10.1111/jipb. 12041

83. Mackenzie B, Loo DDF, Wright EM (1998) Relationships between $\mathrm{Na}(+) /$ glucose cotransporter (SGLT1) currents and fluxes. J Membr Biol 162:101-106. https://doi.org/10.1007/ s002329900347

84. Mager S, KleinbergerDoron N, Keshet GI, Davidson N, Kanner BI, Lester HA (1996) Ion binding and permeation at the GABA transporter GAT1. J Neurosci 16:5405-5414

85. Maillard L (1912) Action des acides amines sur les sucres: formation des melanoidines par voie methodologique. CR Hebd Acad Sci 154:66-68

86. Majumdar DS, Smirnova I, Kasho V, Nir E, Kong X, Weiss S, Kaback HR (2007) Single-molecule FRET reveals sugar-induced conformational dynamics in LacY. Proc Natl Acad Sci U S A 104: 12640-12645. https://doi.org/10.1073/pnas.0700969104

87. McCurdy DW, Dibley S, Cahyanegara R, Martin A, Patrick JW (2010) Functional characterization and RNAi-mediated suppression reveals roles for hexose transporters in sugar accumulation by tomato fruit. Mol Plant 3:1049-1063. https://doi.org/10.1093/mp/ ssq050

88. Meinild AK, Hirayama BA, Wright EM, Loo DD (2002) Fluorescence studies of ligand-induced conformational changes of the $\mathrm{Na}(+) /$ glucose cotransporter. Biochemistry-Us 41:1250 1258. https://doi.org/10.1021/bi011661r 
89. Miller ME, Chourey PS (1992) The maize invertase-deficient miniature-1 seed mutation is associated with aberrant pedicel and endosperm development. Plant Cell 4:297-305. https://doi.org/10. 1105/tpc.4.3.297

90. Milne RJ, Dibley KE, Schnippenkoetter W, Mascher M, Lui ACW, Wang L, Lo C, Ashton AR, Ryan PR, Lagudah ES (2019) The wheat Lr67 gene from the sugar transport protein 13 family confers multipathogen resistance in barley. Plant Physiol 179:1285-1297. https://doi.org/10.1104/pp.18.00945

91. Mitchell P (1963) Molecule, group and electron translocation through the natural membranes. Biochem Soc Symp 22:141-168

92. Monahan-Earley R, Dvorak AM, Aird WC (2013) Evolutionary origins of the blood vascular system and endothelium. J Thromb Haemost 11(Suppl 1):46-66. https://doi.org/10.1111/jth.12253

93. Moore JW, Herrera-Foessel S, Lan C, Schnippenkoetter W, Ayliffe M, Huerta-Espino J, Lillemo M, Viccars L, Milne R, Periyannan S, Kong X, Spielmeyer W, Talbot M, Bariana H, Patrick JW, Dodds P, Singh R, Lagudah E (2015) A recently evolved hexose transporter variant confers resistance to multiple pathogens in wheat. Nat Genet 47:1494-1498. https://doi.org/10. 1038/ng.3439

94. Moran PJ, Thompson GA (2001) Molecular responses to aphid feeding in Arabidopsis in relation to plant defense pathways. Plant Physiol 125:1074-1085. https://doi.org/10.1104/pp.125.2.1074

95. Morsomme P, Boutry M (2000) The plant plasma membrane H(+ )-ATPase: structure, function and regulation. Biochim Biophys Acta 1465:1-16. https://doi.org/10.1016/s0005-2736(00)00128-0

96. Münch E (1930) Die stoffbewegungen in der pflanze. G. Fischer

97. Myburg A, Sederoff R (2001) Xylem structure and function. In: eLS. https://doi.org/10.1038/npg.els.0001302

98. Nagata T, Iizumi S, Satoh K, Kikuchi S (2008) Comparative molecular biological analysis of membrane transport genes in organisms. Plant Mol Biol 66:565-585. https://doi.org/10.1007/s11103007-9287-z

99. Neundlinger I, Puntheeranurak T, Wildling L, Rankl C, Wang LX, Gruber HJ, Kinne RK, Hinterdorfer P (2014) Forces and dynamics of glucose and inhibitor binding to sodium glucose co-transporter SGLT1 studied by single molecule force spectroscopy. J Biol Chem 289:21673-21683. https://doi.org/10.1074/jbc.M113. 529875

100. Norholm MH, Nour-Eldin HH, Brodersen P, Mundy J, Halkier BA (2006) Expression of the Arabidopsis high-affinity hexose transporter STP13 correlates with programmed cell death. FEBS Lett 580:2381-2387. https://doi.org/10.1016/j.febslet.2006.03. 064

101. Nussberger S, Steel A, Trotti D, Romero MF, Boron WF, Hediger MA (1997) Symmetry of H+ binding to the intra- and extracellular side of the H+-coupled oligopeptide cotransporter PepT1. J Biol Chem 272:7777-7785. https://doi.org/10.1074/jbc.272.12.7777

102. Ohtani M, Akiyoshi N, Takenaka Y, Sano R, Demura T (2017) Evolution of plant conducting cells: perspectives from key regulators of vascular cell differentiation. J Exp Bot 68:17-26. https:// doi.org/10.1093/jxb/erw473

103. Otori K, Tanabe N, Tamoi M, Shigeoka S (2019) Sugar transporter protein 1 (STP1) contributes to regulation of the genes involved in shoot branching via carbon partitioning in Arabidopsis. Biosci Biotechnol Biochem 83:472-481. https://doi.org/10.1080/ 09168451.2018 .1550355

104. Palmgren MG (2001) Plant plasma membrane H+-ATPases: powerhouses for nutrient uptake. Annu Rev Plant Physiol Plant Mol Biol 52:817-845. https://doi.org/10.1146/annurev.arplant.52.1. 817

105. Pao SS, Paulsen IT, Saier MH Jr (1998) Major facilitator superfamily. Microbiol Mol Biol Rev 62:1-34

106. Parent L, Supplisson S, Loo DD, Wright EM (1992) Electrogenic properties of the cloned $\mathrm{Na}+$ glucose cotransporter: I. Voltage- clamp studies. J Membr Biol 125:49-62. https://doi.org/10.1007/ BF00235797

107. Parent L, Supplisson S, Loo DDF, Wright EM (1992) Electrogenic properties of the cloned $\mathrm{Na}+$ glucose cotransporter .2. A transport model under nonrapid equilibrium conditions. $\mathrm{J}$ Membr Biol 125:63-79

108. Patching SG, Baldwin SA, Baldwin AD, Young JD, Gallagher MP, Henderson PJ, Herbert RB (2005) The nucleoside transport proteins, NupC and NupG, from Escherichia coli: specific structural motifs necessary for the binding of ligands. Org Biomol Chem 3:462-470. https://doi.org/10.1039/b414739a

109. Paulsen PA, Custodio TF, Pedersen BP (2019) Crystal structure of the plant symporter STP10 illuminates sugar uptake mechanism in monosaccharide transporter superfamily. Nat Commun 10:407. https://doi.org/10.1038/s41467-018-08176-9

110. Pedersen CN, Axelsen KB, Harper JF, Palmgren MG (2012) Evolution of plant p-type ATPases. Front Plant Sci 3:31. https:// doi.org/10.3389/fpls.2012.00031

111. Pittermann J (2010) The evolution of water transport in plants: an integrated approach. Geobiology 8:112-139. https://doi.org/10. 1111/j.1472-4669.2010.00232.x

112. Popp C, Gorboulev V, Muller TD, Gorbunov D, Shatskaya N, Koepsell H (2005) Amino acids critical for substrate affinity of rat organic cation transporter 1 line the substrate binding region in a model derived from the tertiary structure of lactose permease. Mol Pharmacol 67:1600-1611. https://doi.org/10.1124/mol.104. 008839

113. Poschet G, Hannich B, Buttner M (2010) Identification and characterization of AtSTP14, a novel galactose transporter from Arabidopsis. Plant Cell Physiol 51:1571-1580. https://doi.org/ $10.1093 /$ pcp/pcq100

114. Quick M, Tomasevic J, Wright EM (2003) Functional asymmetry of the human $\mathrm{Na}+$ glucose transporter (hSGLT1) in bacterial membrane vesicles. Biochemistry-Us 42:9147-9152. https://doi. org/10.1021/bi034842x

115. Rausch T (1991) The hexose transporters at the plasma-membrane and the tonoplast of higher-plants. Physiol Plant 82:134-142

116. Raven JA (2003) Long-distance transport in non-vascular plants. Plant Cell Environ 26:73-85. https://doi.org/10.1046/j.13653040.2003.00920.x

117. Reddy VS, Shlykov MA, Castillo R, Sun EI, Saier MH Jr (2012) The major facilitator superfamily (MFS) revisited. FEBS J 279: 2022-2035. https://doi.org/10.1111/j.1742-4658.2012.08588.x

118. Rennie EA, Turgeon R (2009) A comprehensive picture of phloem loading strategies. Proc Natl Acad Sci U S A 106:1416214167. https://doi.org/10.1073/pnas.0902279106

119. Riesmeier JW, Willmitzer L, Frommer WB (1992) Isolation and characterization of a sucrose carrier cDNA from spinach by functional expression in yeast. EMBO J 11:4705-4713

120. Riesmeier JW, Willmitzer L, Frommer WB (1994) Evidence for an essential role of the sucrose transporter in phloem loading and assimilate partitioning. EMBO J 13:1-7

121. Roitsch T, Tanner W (1994) Expression of a sugar-transporter gene family in a photoautotrophic suspension culture of Chenopodium rubrum L. Planta 193:365-371. https://doi.org/10. 1007/BF00201814

122. Rottmann T, Zierer W, Subert C, Sauer N, Stadler R (2016) STP10 encodes a high-affinity monosaccharide transporter and is induced under low-glucose conditions in pollen tubes of Arabidopsis. J Exp Bot 67:2387-2399. https://doi.org/10.1093/ jxb/erw048

123. Rottmann T, Fritz C, Sauer N, Stadler R (2018) Glucose uptake via STP transporters inhibits in vitro pollen tube growth in a hexokinase1-dependent manner in Arabidopsis thaliana. Plant Cell 30:2057-2081. https://doi.org/10.1105/tpc.18.00356 
124. Rottmann T, Klebl F, Schneider S, Kischka D, Ruscher D, Sauer N, Stadler R (2018) Sugar transporter STP7 specificity for 1Arabinose and d-Xylose contrasts with the typical hexose transporters STP8 and STP12. Plant Physiol 176:2330-2350. https:// doi.org/10.1104/pp.17.01493

125. Saier MH Jr, Tran CV, Barabote RD (2006) TCDB: the Transporter Classification Database for membrane transport protein analyses and information. Nucleic Acids Res 34:D181D186. https://doi.org/10.1093/nar/gkj001

126. Sauer N, Stadler R (1993) A sink-specific H+/monosaccharide cotransporter from Nicotiana tabacum: cloning and heterologous expression in baker's yeast. Plant J 4:601-610. https://doi.org/10. 1046/j.1365-313x.1993.04040601.x

127. Sauer N, Stolz J (1994) SUC1 and SUC2: two sucrose transporters from Arabidopsis thaliana; expression and characterization in baker's yeast and identification of the histidine-tagged protein. Plant J 6:67-77. https://doi.org/10.1046/j.1365-313x.1994. 6010067.x

128. Sauer N, Caspari T, Klebl F, Tanner W (1990) Functional expression of the Chlorella hexose transporter in Schizosaccharomyces pombe. Proc Natl Acad Sci U S A 87:7949-7952. https://doi.org/ 10.1073/pnas.87.20.7949

129. Sauer N, Friedlander K, Graml-Wicke U (1990) Primary structure, genomic organization and heterologous expression of a glucose transporter from Arabidopsis thaliana. EMBO J 9:3045-3050

130. Schafer N, Friedrich M, Jorgensen ME, Kollert S, Koepsell H, Wischmeyer E, Lesch KP, Geiger D, Doring F (2018) Functional analysis of a triplet deletion in the gene encoding the sodium glucose transporter 3, a potential risk factor for ADHD. PLoS One 13:e0205109. https://doi.org/10.1371/journal.pone. 0205109

131. Schneidereit A, Scholz-Starke J, Buttner M (2003) Functional characterization and expression analyses of the glucose-specific AtSTP9 monosaccharide transporter in pollen of Arabidopsis. Plant Physiol 133:182-190. https://doi.org/10.1104/pp.103. 026674

132. Schneidereit A, Scholz-Starke J, Sauer N, Buttner M (2005) AtSTP11, a pollen tube-specific monosaccharide transporter in Arabidopsis. Planta 221:48-55. https://doi.org/10.1007/s00425004-1420-5

133. Schofield RA, Bi YM, Kant S, Rothstein SJ (2009) Overexpression of STP13, a hexose transporter, improves plant growth and nitrogen use in Arabidopsis thaliana seedlings. Plant Cell Environ 32:271-285. https://doi.org/10.1111/j.1365-3040.2008. 01919.x

134. Scholz-Starke J, Buttner M, Sauer N (2003) AtSTP6, a new pollen-specific H+-monosaccharide symporter from Arabidopsis. Plant Physiol 131:70-77. https://doi.org/10.1104/pp.012666

135. Schuetz M, Smith R, Ellis B (2013) Xylem tissue specification, patterning, and differentiation mechanisms. J Exp Bot 64:11-31. https://doi.org/10.1093/jxb/ers287

136. Schumacher K (2006) Endomembrane proton pumps: connecting membrane and vesicle transport. Curr Opin Plant Biol 9:595-600. https://doi.org/10.1016/j.pbi.2006.09.001

137. Scofield GN, Hirose T, Aoki N, Furbank RT (2007) Involvement of the sucrose transporter, OsSUT1, in the long-distance pathway for assimilate transport in rice. J Exp Bot 58:3155-3169. https:// doi.org/10.1093/jxb/erm 153

138. Segami S, Asaoka M, Kinoshita S, Fukuda M, Nakanishi Y, Maeshima M (2018) Biochemical, structural and physiological characteristics of vacuolar H+-pyrophosphatase. Plant Cell Physiol 59:1300-1308. https://doi.org/10.1093/pcp/pcy054

139. Sherson SM, Alford HL, Forbes SM, Wallace G, Smith SM (2003) Roles of cell-wall invertases and monosaccharide transporters in the growth and development of Arabidopsis. J Exp Bot 54:525-531. https://doi.org/10.1093/jxb/erg055
140. Slewinski TL (2011) Diverse functional roles of monosaccharide transporters and their homologs in vascular plants: a physiological perspective. Mol Plant 4:641-662. https://doi.org/10.1093/mp/ ssr051

141. Slewinski TL, Braun DM (2010) Current perspectives on the regulation of whole-plant carbohydrate partitioning. Plant Sci 178: 341-349. https://doi.org/10.1016/j.plantsci.2010.01.010

142. Slewinski TL, Meeley R, Braun DM (2009) Sucrose transporter1 functions in phloem loading in maize leaves. J Exp Bot 60:881892. https://doi.org/10.1093/jxb/ern335

143. Smirnova IN, Kasho V, Kaback HR (2008) Protonation and sugar binding to LacY. Proc Natl Acad Sci U S A 105:8896-8901. https://doi.org/10.1073/pnas.0803577105

144. Smirnova I, Kasho V, Sugihara J, Kaback HR (2013) Trp replacements for tightly interacting Gly-Gly pairs in LacY stabilize an outward-facing conformation. Proc Natl Acad Sci U S A 110: 8876-8881. https://doi.org/10.1073/pnas.1306849110

145. Smirnova I, Kasho V, Jiang X, Pardon E, Steyaert J, Kaback HR (2014) Outward-facing conformers of LacY stabilized by nanobodies. Proc Natl Acad Sci U S A 111:18548-18553. https://doi.org/10.1073/pnas.1422265112

146. Smirnova I, Kasho V, Jiang X, Pardon E, Steyaert J, Kaback HR (2015) Transient conformers of LacY are trapped by nanobodies. Proc Natl Acad Sci U S A 112:13839-13844. https://doi.org/10. 1073/pnas.1519485112

147. Snyder PW, Mecinovic J, Moustakas DT, Thomas SW, Harder M, Mack ET, Lockett MR, Heroux A, Sherman W, Whitesides GM (2011) Mechanism of the hydrophobic effect in the biomolecular recognition of arylsulfonamides by carbonic anhydrase. Proc Natl Acad Sci U S A 108:17889-17894. https://doi.org/10.1073/pnas. 1114107108

148. Srivastava AC, Ganesan S, Ismail IO, Ayre BG (2008) Functional characterization of the Arabidopsis AtSUC2 Sucrose/H+ symporter by tissue-specific complementation reveals an essential role in phloem loading but not in long-distance transport. Plant Physiol 148:200-211. https://doi.org/10.1104/pp.108.124776

149. Stadler R, Brandner J, Schulz A, Gahrtz M, Sauer N (1995) Phloem loading by the Pmsuc2 sucrose carrier from PlantagoMajor occurs into companion cells. Plant Cell 7:1545-1554

150. Stadler R, Buttner M, Ache P, Hedrich R, Ivashikina N, Melzer M, Shearson SM, Smith SM, Sauer N (2003) Diurnal and lightregulated expression of AtSTP1 in guard cells of Arabidopsis. Plant Physiol 133:528-537. https://doi.org/10.1104/pp.103. 024240

151. Stein WD (1995) The sodium pump in the evolution of animal cells. Philos Trans R Soc Lond Ser B Biol Sci 349:263-269. https://doi.org/10.1098/rstb.1995.0112

152. Stein WD (2002) Cell volume homeostasis: ionic and nonionic mechanisms. The sodium pump in the emergence of animal cells. Int Rev Cytol 215:231-258. https://doi.org/10.1016/s00747696(02)15011-x

153. Su A, Mager S, Mayo SL, Lester HA (1996) A multi-substrate single-file model for ion-coupled transporters. Biophys J 70:762 777. https://doi.org/10.1016/S0006-3495(96)79616-9

154. Subtil T, Boles E (2011) Improving L-arabinose utilization of pentose fermenting Saccharomyces cerevisiae cells by heterologous expression of L-arabinose transporting sugar transporters. Biotechnol Biofuels 4:38. https://doi.org/10.1186/1754-6834-438

155. Sun LF, Zeng X, Yan CY, Sun XY, Gong XQ, Rao Y, Yan NE (2012) Crystal structure of a bacterial homologue of glucose transporters GLUT1-4. Nature 490:361. https://doi.org/10.1038/ nature 11524

156. Sutton PN, Gilbert MJ, Williams LE, Hall JL (2007) Powdery mildew infection of wheat leaves changes host solute transport 
and invertase activity. Physiol Plant 129:787-795. https://doi.org/ 10.1111/j.1399-3054.2007.00863.x

157. Sze H (1985) H-translocating ATPase: advances using membrane vesicles. Annu Rev Plant Physiol 36:175-208

158. Tanner W (1969) Light-driven active uptake of 3-Omethylglucose via an inducible hexose uptake system of Chlorella. Biochem Biophys Res Commun 36:278-283. https:// doi.org/10.1016/0006-291x(69)90326-x

159. Thornalley PJ (2003) Glyoxalase I: structure, function and a critical role in the enzymatic defense against glycation. Biochem Soc Trans 31:1343-1348

160. Truernit E, Schmid J, Epple P, Illig J, Sauer N (1996) The sinkspecific and stress-regulated Arabidopsis STP4 gene: enhanced expression of a gene encoding a monosaccharide transporter by wounding, elicitors, and pathogen challenge. Plant Cell 8:21692182. https://doi.org/10.1105/tpc.8.12.2169

161. Truernit E, Stadler R, Baier K, Sauer N (1999) A male gametophyte-specific monosaccharide transporter in Arabidopsis. Plant J 17:191-201. https://doi.org/10.1046/j.1365313x.1999.00372.x

162. Turk E, Wright EM (1997) Membrane topology motifs in the SGLT cotransporter family. J Membr Biol 159:1-20. https://doi. org/10.1007/s002329900264

163. Turk E, Kim O, le Coutre J, Whitelegge JP, Eskandari S, Lam JT, Kreman M, Zampighi G, Faull KF, Wright EM (2000) Molecular characterization of Vibrio parahaemolyticus vSGLT - a model for sodium-coupled sugar cotransporters. J Biol Chem 275:2571125716. https://doi.org/10.1074/jbc.M003127200

164. Uldry M, Thorens B (2004) The SLC2 family of facilitated hexose and polyol transporters. Pflugers Arch - Eur J Physiol 447:480489. https://doi.org/10.1007/s00424-003-1085-0

165. Van Bel AJE (2003) The phloem, a miracle of ingenuity. Plant Cell Environ 26:125-149. https://doi.org/10.1046/j.1365-3040. 2003.00963.x

166. Vardy E, Arkin IT, Gottschalk KE, Kaback HR, Schuldiner S (2004) Structural conservation in the major facilitator superfamily as revealed by comparative modeling. Protein Sci 13:1832-1840. https://doi.org/10.1110/ps.04657704

167. von Schaewen A, Stitt M, Schmidt R, Sonnewald U, Willmitzer L (1990) Expression of a yeast-derived invertase in the cell wall of tobacco and Arabidopsis plants leads to accumulation of carbohydrate and inhibition of photosynthesis and strongly influences growth and phenotype of transgenic tobacco plants. EMBO J 9: 3033-3044

168. Watanabe A, Choe S, Chaptal V, Rosenberg JM, Wright EM, Grabe M, Abramson J (2010) The mechanism of sodium and substrate release from the binding pocket of vSGLT. Nature 468:988-U162. https://doi.org/10.1038/nature09580

169. Williams LE, Lemoine R, Sauer N (2000) Sugar transporters in higher plants - a diversity of roles and complex regulation. Trends Plant Sci 5:283-290. https://doi.org/10.1016/s1360-1385(00) 01681-2

170. Wind J, Smeekens S, Hanson J (2010) Sucrose: metabolite and signaling molecule. Phytochemistry 71:1610-1614. https://doi. org/10.1016/j.phytochem.2010.07.007

171. Wisedchaisri G, Park MS, Iadanza MG, Zheng H, Gonen T (2014) Proton-coupled sugar transport in the prototypical major facilitator superfamily protein XylE. Nat Commun 5:4521. https://doi.org/ $10.1038 /$ ncomms 5521

172. Wood JM, Culham DE, Hillar A, Vernikovska YI, Liu F, Boggs JM, Keates RAB (2005) A structural model for the osmosensor, transporter, and osmoregulator ProP of Escherichia coli. Biochemistry-Us 44:5634-5646. https://doi.org/10.1021/ bi047383o

173. Wright EM, Turk E (2004) The sodium/glucose cotransport family SLC5. Pflugers Arch - Eur J Physiol 447:510-518. https://doi. org/10.1007/s00424-003-1063-6

174. Wright EMLD, Hirayama BA, Turk E (2006) Sugar absorption. In: Johnson L (ed) Physiology of the Gastrointestinal Tract, 4th edn. Elsevier/Academic Press, San Diego

175. Wright EM, Hirayama BA, Loo DF (2007) Active sugar transport in health and disease. J Intern Med 261:32-43. https://doi.org/10. 1111/j.1365-2796.2006.01746.x

176. Wright EM, Loo DD, Hirayama BA (2011) Biology of human sodium glucose transporters. Physiol Rev 91:733-794. https:/ doi.org/10.1152/physrev.00055.2009

177. Yamada K, Kanai M, Osakabe Y, Ohiraki H, Shinozaki K, Yamaguchi-Shinozaki K (2011) Monosaccharide absorption activity of Arabidopsis roots depends on expression profiles of transporter genes under high salinity conditions. J Biol Chem 286: 43577-43586. https://doi.org/10.1074/jbc.M111.269712

178. Yamada K, Saijo Y, Nakagami H, Takano Y (2016) Regulation of sugar transporter activity for antibacterial defense in Arabidopsis. Science 354:1427-1430. https://doi.org/10.1126/science.aah5692

179. Yamada K, Osakabe Y, Yamaguchi-Shinozaki K (2017) A Cterminal motif contributes to the plasma membrane localization of Arabidopsis STP transporters. PLoS One 12:e186326. https://doi.org/10.1371/journal.pone.0186326

180. Yamashita A, Singh SK, Kawate T, Jin Y, Gouaux E (2005) Crystal structure of a bacterial homologue of $\mathrm{Na}+\mathrm{Cl}-$ dependent neurotransmitter transporters. Nature 437:215-223. https://doi. org/10.1038/nature03978

181. Yamauchi Y, Ejiri Y, Tanaka K (2002) Glycation by ascorbic acid causes loss of activity of ribulose-1,5-bisphosphate carboxylase/ oxygenase and its increased susceptibility to proteases. Plant Cell Physiol 43:1334-1341. https://doi.org/10.1093/pcp/pcf162

182. Zhang XC, Zhao Y, Heng J, Jiang D (2015) Energy coupling mechanisms of MFS transporters. Protein Sci 24:1560-1579. https://doi.org/10.1002/pro.2759

183. Zhou JJ, Miller AJ (2000) Comparison of the transport properties of three plant sucrose carriers expressed in Xenopus oocytes. Aust J Plant Physiol 27:725-732

184. Zhou Y, Guan L, Freites JA, Kaback HR (2008) Opening and closing of the periplasmic gate in lactose permease. Proc Natl Acad Sci U S A 105:3774-3778. https://doi.org/10.1073/pnas. 0800825105

185. Zimmer A, Lang D, Richardt S, Frank W, Reski R, Rensing SA (2007) Dating the early evolution of plants: detection and molecular clock analyses of orthologs. Mol Gen Genomics 278:393402. https://doi.org/10.1007/s00438-007-0257-6

186. Zimmermann M, Ziegler H (1975) List of sugar and sugar alcohols in sieve-tube exudates. Encycl Plant Physiol:479-503

187. Zuniga FA, Shi GP, Haller JF, Rubashkin A, Flynn DR, Iserovich P, Fischbarg J (2001) A three-dimensional model of the human facilitative glucose transporter Glut1. J Biol Chem 276:44970 44975. https://doi.org/10.1074/jbc.M107350200

Publisher's note Springer Nature remains neutral with regard to jurisdictional claims in published maps and institutional affiliations. 